\title{
The Psilidae (Diptera, Acalyptrata) of Switzerland, with description of two new species from Central Europe
}

\author{
Anatole I. SHATALKIN ${ }^{1} \&$ Bernhard MERZ $^{2}$ \\ ${ }^{1}$ Zoological Museum, Moscow State University, B. Nikitskaja str. 6, K-9, \\ 103009 Moscow, Russia. \\ E-mail: shatalkin@zmmu.msu.ru \\ ${ }^{2}$ Muséum d'histoire naturelle Genève, C. P. 6434, 1211 Genève, Switzerland. \\ E-mail: bernhard.merz@ville-ge.ch
}

\begin{abstract}
The Psilidae (Diptera, Acalyptrata) of Switzerland, with description of two new species from Central Europe. - The family Psilidae is reviewed for Switzerland and data are listed for all species currently known from this country. Chamaepsila sardoa (Rondani) and Ch. unilineata (Zetterstedt) are recorded for the first time from Switzerland. Psila (s. str.) helvetica sp. $\mathrm{n}$. (Switzerland) and Chamaepsila confusa sp. n. (France, Switzerland) are described and illustrated. Keys for the European species of Psila s. str. Meigen and the Chamaepsila pallida group are provided. A summary of diagnostic characters of the genera of Psila s. lat. is given. An updated checklist of the 36 Swiss species is presented.
\end{abstract}

Keywords: Psilidae - Switzerland - new species - keys - checklist.

\section{INTRODUCTION}

The Psilidae are a small family of acalyptrate Diptera with 335 species described from all biogeographical regions. Most species occur in the Holarctic Region with 153 species currently known from the Palaearctic Region. They are considered to be monophyletic with some well-supported apomorphic character states: wing venation peculiar (the costa has a break at the distal end of the subcosta which is reaching the costa as a fold; the distal margin of cell cup (anal cell, posterior cubital cell) is closed by a straight vein $\mathrm{CuA} 2)$ and chaetotaxy reduced (0-1 notopleural setae; acrostichal setulae usually not differentiated; pleuron bare or covered with setulae, but without setae).

Traditionally, the family is divided into two subfamilies, the Chylizinae and the Psilinae. The Chylizinae (116 species worldwide, particularly numerous in the Afrotropical and Oriental Regions, 22 species in the Palaearctic Region) are probably plesiomorphic whereas the Psilinae (216 species described mainly from the Holarctic Region, few species in the Afrotropical and Oriental Regions, unknown in the Neotropics) are usually considered to be a monophyletic group. The Psilinae consist mainly of slender species ranging from $3 \mathrm{~mm}$ (often in Psila s. lat.) to $13 \mathrm{~mm}$ (some Loxocera spp.). They have usually a triangular head with a receding face in profile.

Manuscript accepted 09.06.2010 
Their parafacialia lacks silvery white microtrichia. The male terminalia are characterized by well-developed parameres and by the absence of a surstylus. The Chylizinae are more stumpy flies and differ from the Psilinae by the developed postcoxal bridge and the presence of a surstylus in the male. Their parafacialia is silvery microtrichose. McAlpine (1997) considered this last character as groundplan condition of Diopsoidea (Diopsidae and Syringogastridae), but it is also present in some species of other families (Megamerinidae, Strongylophthalmyiidae, Tanypezidae).

Recently, Shatalkin (2001) proposed a third subfamily, the Belobackenbardiinae for three species of Belobackenbardia Shatalkin from South Africa. They are externally similar to primitive species of Psila s. lat., but their parafacialia is silvery microtrichose. Also, their male terminalia do not have any resemblance with those of other Psilidae and related families. It is possible that their similarity with Psila s. lat. is due to convergence.

The known larvae of Psilidae are phytophagous (Ferrar, 1987; Iwasa, 1998). They are tunneling in stems, rootstocks and bulbs, or live under the bark of thin twigs of trees. The larvae of the common European species Chyliza leptogaster (Panzer) may cause phloem necroses in deciduous trees (Dengler, 1997). Those of Chyliza annulipes Macquart have been recorded from conifers, in particular from resinous wounds (Lyneborg, 1987). Chyliza vittata has been reared from mines in stems and roots of Orchidaceae (de Meijere, 1940; Petit, 1982) whereas the larvae of the externally similar Chinese Chyliza bambusae Yang \& Wang develop in roots of bamboo (Yang \& Wang, 1988). The Nearctic Chyliza leguminicola Melander is feeding from the lower part of Lupinus polyphyllus (Melander, 1920). Species of Loxocera and some Psila s. lat. are often found in marshland where their larvae are developing in stems of Cyperaceae (Carex) or Juncaceae (Juncus).

Only few species of the family are of economic importance. The larvae of the carrot fly, Chamaepsila rosae (Fabricius), may cause important damage in edible roots of carrots and other umbelliferous crops (celery [= Apium graveolens], parsley [= Petroselinum hortense], parsnip [= Pastinaca sativa $]$ ) and some cruciferous species (cabbage [= Brassica sp.], turnip [= Brassica rapa $]$ ). Another pest species is Chamaepsila nigricornis (Meigen) whose larvae feed in roots of ornamental plants.

\section{REVIEW OF THE FAUNISTIC RESEARCH IN SWITZERLAND}

Switzerland is a small country in Central Europe but of a remarkable diversity with currently almost 7'000 species of Diptera recorded (Merz et al., 2007). This may be explained by the presence of species which are widely distributed in temperate Central Europe living in various types of grassland from swamps to rather dry meadows and in deciduous and evergreen forests. In addition, a notable influence of the Mediterranean fauna may be recorded in Southern Switzerland and the region of Geneva. The dry Central Alpine valleys are famous for some steppose, East European species. Finally, numerous Scandinavian or boreal species were found in Subalpine and Alpine Regions of the Alps and the Jura chain.

The Psilidae of Switzerland have never been studied. The only historical list with six reliable records was published by Ringdahl (1957). Later, Merz (1998) established the Swiss checklist with 31 species based on about 600 specimens housed 
in the 10 most important public collections of Switzerland. However, no data with precise information (localities, dates of collecting) were provided. One species, Loxocera maculata, was later added by Merz et al. (2002).

The motivation of the present paper is threefold. First, the knowledge of the Swiss fauna is reviewed with inclusion of distributional data for all species and a revised checklist is provided here in the appendix. Second, the occasion is taken to describe two species new to science which were discovered during the preparation of the paper. And finally, updated keys are given for some taxonomically difficult groups in the light of new results which were obtained by the study of the present specimens.

\section{MATERIAL AND METHODS}

This study is based on about 330 specimens which were almost exclusively collected in Switzerland $(\mathrm{CH})$ and which are deposited in the collection of the Natural History Museum Geneva (MHNG). Few duplicate specimens are also kept in the Zoological Museum of the Moscow State University (ZMUM). In addition, the type series of one species, Scatophaga pallida Fallén, deposited in the Swedish Museum of Natural History (NRS) was examined.

The responsabilities are distributed as follows: The first author identified at least one specimen of each species. He prepared a draft version of the manuscript with the descriptions and illustrations of the species and with the elaboration of the new facts and keys arising from the study of the specimens. The second author identified further specimens of almost all species and he prepared an updated version of the manuscript.

For identification, the following keys and revisions were used: Hennig (1941), Collin (1944), Lyneborg (1964), Shatalkin (1986), Wang (1988), Greve \& Midtgaard (1989), Shtakel'berg (1989), Carles-Tolrá (1993a), van der Goot \& van Veen (1996), Iwasa (1998), and Greve \& Skartveit (2000). Data about the distribution of the species in Europe is partly taken from Pape (2007).

Terminology and nomenclature in the systematic part follows basically Iwasa (1998) and Merz \& Haenni (2000). The genera are arranged in a phylogenetic order and the species alphabetically within the genera. The specimens are listed in alphabetical order for cantons.

\section{SYSTEMATIC PART}

\section{SubFAmily ChylizinAE}

This subfamily includes the single genus Chyliza. It is characterized by the following unique combination of characters: anatergal area of laterotergite enlarged, callus-like; occiput concave; face nearly perpendicular, not retreating; head not triangular in profile; usually three (pairs of) scutellar setae; postcoxal bridge developed; anal cell (posterior cubital cell, cup) shorter than 2nd basal cell.

Genus Chyliza Fallén, 1820

TYPE SPECIES: Musca leptogaster Panzer, 1798, by subsequent designation of Westwood, 1840: 146. 
Comments: In Europe, five species are recognized (Hennig, 1941; Soós, 1984) which all occur in Switzerland. "Chyliza" gracilis Loew, 1854, is considered here to belong to the subfamily Psilinae (see below).

\section{Chyliza annulipes Macquart, 1835}

Material Switzerland: $10^{\star}$, GE, Corsier-Port, vitre véranda, 27-31 V 2005, leg. C. Besuchet. - 1ठ , ZH, 400 m, Embrach-Haumüli, 9 V 1998, leg. B. Merz. - 1o, 1 q , ZH, 460 m, Zürich-Ziegelhütte, $10 \mathrm{~V}$ 1997, leg. B. Merz.

\section{Chyliza extenuata (Rossi, 1790)}

Material Switzerland: 10 , 1 ㅇ, FR, 460-650 m, Mt. Vully, Bas Vully, 6 VI 2003, leg. B. Merz \& F. Amiet. - 1ठ, GE, 510 m, Bernex, Signal, 24 V 2002, leg. B. Merz. - 10 , GE, Corsier-Port, vitre véranda, 1-31 V 2009, C. Besuchet.

Comments: Larvae develop in roots of broomrapes (Orobanche spp.). Outside of Europe this species is recorded from Central Asia.

\section{Chyliza leptogaster (Panzer, 1798)}

Material Switzerland: 10 , GE, Corsier-Port, vitre véranda, 20-30 VI 2008, leg. C. Besuchet. -2 , , GE, 350 m, Chancy, La Laire, 1 VII 2001, leg. B. Merz. - 1 ㅇ, GE, 500 m, Bernex-Signal, 17 VI 2009, B. Merz. - 1 o, GR, 980 m, Andeer-Clugin, 17 V 1994, leg. B. Merz. - 1 \%, SG, 610 m, Wattwil, 11 VII 1997, leg. B. Merz. - 10, TI, 350 m, Biasco-Loderio, 7180/1375, 16 V 2006, leg. B. Merz. - 1q, TI, 600-1100 m, Monte San Giorgio, 717180/085700, 5 VII 2001, leg. B. Merz. - 1 \%, VS, 750 m, Branson/Follatères, 9 VI 2004, leg. B. Merz \& J.-P. Haenni. - 1 \%, VS, 700-770 m, Raron-Heidnischbiel, 26 V 1999, leg. B. Merz. -1 q, VS, 750 m, Raron-Heidnischbiel, 3 VII 2003, leg. Merz, Smit \& van Det. - 10 , VS, 625 m, Leuk-Platten, 8 VI 2001, leg. B. Merz \& B. Landry. - 1ㅇ, ZH, 650 m, Zürich-Zürichberg, 26 VII 1995, M.Fal [Malaise trap], S.Ungricht.

\section{Chyliza nova Collin, 1944}

Material Switzerland: 19 , GE, 440 m, Bernex-Saule, 14 VI 2009, B. Merz. $-1 q$, GE, 440 m, Bernex-Saule, 19 VI 2008, leg. B. Merz. - 1 \% , GE, 440 m, Bernex-Signal, 25 VI 2009, B. Merz. - 1 ô, GE, Corsier-Port, vitre véranda, 1-30 VI 2004, leg. C. Besuchet. - 1 , VD, Bonvillars, La Coudre, 10 VII 1991, leg. J. Steffen. - 1 ô, ZH, 450 m, Zürich-Waldgarten, 24 V 1996, leg. B. Merz. - 1 б, ZH, 460 m, Zürich-Ziegelhütte, 29 VI 1997, leg. B. Merz.

\section{Chyliza vittata Meigen, 1826}

Material Switzerland: 1 q , BE, 650-950 m, Mt. Raimeux, Corcelles, 2 VI 2003, leg. B. Merz. - 1 ô, GE, 350 m, Cartigny, Moulin de Vert, 24 V 1999, leg. Merz \& Müller.

\section{SubFAmily PsiLINAE}

\section{Tribe Loxocerini}

COMmENTs: Traditionally, this tribe includes Psila-like flies which are charac terized by a long postpedicel which is longer than the head, and by a pad of short setulae which are often present near the ventral tip of the hind femur. In Europe, this tribe is represented by the genus Loxocera s. lat. (see below). Shatalkin (1998) pro posed a new subgenus, Asiopsila Shatalkin, for Oriental species of small size (3.5-5 $\mathrm{mm}$ ) without the pad of short setulae on the hind femur but with a whitish spot in the upper part of the katepisternum. Later, Buck \& Marshall (2006b) transferred this subgenus in the tribe Psilini where it is considered to be a subgenus of Psila s. str. Their 
conclusion seems to be justified. However, it should be noted that the structure of the male terminalia with the reduced parameres in Asiopsila differs strongly from the superficially similar external morphology in other taxa of the Psilini. In this respect they resemble species of Loxocera s. lat. Following this conclusion Loxocera glandicula Iwasa, 1993, which is close to L. aristata, is the only Oriental species of Loxocera s. str.

Hennig (1941) and Steyskal (1987) treated Platystyla Macquart, 1835, as a subgenus of Loxocera. Species of Platystyla are characterized by extremely long antennal segments and a strongly thickened and flattened arista which is inserted near the middle of the postpedicel or even more apically (the part distal of the insertion of the arista on the postpedicel is 1.0-1.3 times as long as the part basal of it). Earlier, Frey (1925) treated Loxocera and Platystyla as distinct genera and he proposed the new subgenus Imantimyia Frey within Loxocera for Loxocera albiseta (Schrank) and morphologically similar species (L. sylvatica and L. fulviventris). Recently, Buck \& Marshall (2006b) proposed a new classification based on a phylogenetic study of Nearctic and Palaearctic Loxocerini, in particular of the egg structure and the male terminalia. They concluded that Loxocera sensu Frey (1925) or Hennig (1941) is paraphyletic and they suggested that Imantimyia is the sister-group of (Loxocera s. str. + Platystyla). As a consequence of this phylogenetic study they treat Imantimyia and Platystyla as subgenera of Loxocera. However, based on its morphological peculiarities with the strongly modified antennae it is difficult to accept the proposition that Platystyla with its 5 Oriental and Palaearctic species (Frey, 1955) should be considered as subgenus of Loxocera. In order to preserve the new phylogenetic hypothesis of Buck \& Marshall (2006b) the following concept is proposed here: Imantimyia is treated as a separate genus, whereas Platystyla is placed as subgenus within Loxocera. Following this proposition it should be noted that Tropeopsila Shatalkin, 1983, described for two East Palaearctic species and which was not studied by Buck \& Marshall (2006b), is a subgenus of Loxocera.

Species of Loxocera and Imantimyia develop in stalks of sedges (de Meijere, 1941; Chandler, 1975; Ferrar, 1987). The tribe contains currently 54 species; 18 species are known from the Palaearctic Region. All 7 European species (Pape, 2007) occur in Switzerland.

Genus Loxocera Meigen, 1803

TYPE SPECIES: Musca aristata Panzer, 1801, by monotypy.

COMMENTS: In the current interpretation, Loxocera is a well characterized genus. It differs from the other genus of the tribe, Imantimyia, by the following characters (see also Buck \& Marshall, 2006b): frons with a pair of desclerotized velvety vittae; lunule semicircular between antennal bases and anterior margin of frons, crest-like (usually hidden in Imantimyia); alula bare at least medially; male pregenital sclerite large and setulose (small and bare in Imantimyia); female cerci not fused with tergite 10 (fused in Imantimyia).

According to the present concept, the genus contains besides the nominal subgenus also the two subgenera Platystyla Macquart and Tropeopsila Shatalkin. In Europe, two species of Loxocera s. str. and one species of Platystyla are known, all occurring also in Switzerland. 
Subgenus Loxocera Meigen, 1803

Loxocera (s. str.) aristata (Panzer, 1801)

Material Switzerland: 1 , BE, 995 m, Tramelan, La Tourbière, 4 VI 2003, Merz, Haenni \& Rapp. - 1 q , GE, 400 m, Bernex, Chante-Merle, 1 VI 2009, leg. B. Merz. - 1 q , GE, 420 m, Bernex, Bois des Mouilles, 19 VIII 2006, leg. B. Merz. - 1 \% , GE, Corsier-Port, vitre véranda. 1-15 IX 2008, C. Besuchet. - 10 \$, GE, Corsier-Port, vitre véranda, 27-31 V 2005, leg. C. Besuchet. -1 , GL, 1500 m, Pragelpass, 5 VIII 1991, leg. Bächli, Beuk, Merz. - 1 \% , JU, 1020 m, Les Breuleux, La Tourbière, 4 VI 2003, leg. Merz, Haenni \& Rapp. - 1 , JU, 1000 m, La Chaux-des-Breuleux, La Tourbière, 28 VI 2003, leg. B. Merz. - 1 , VS, 1700-1900 m, Morgins, La Chaux-Culet, 21 VI 2003, leg. B. Merz. - 1 \% , VS, 1700-1900 m, Morgins-En Tey, 22 VI 2003, leg. B. Merz.

Loxocera (s. str.) maculata Rondani, 1876

Figs P1-P2

Material Switzerland: 40 , 5 + , VS, 2000 m, Simplon/Hospiz, 645450/121680, 4 VII 2001, leg. B. Merz.

COMMENTS: The status of this species is subject to different interpretations. Some authors synonymized L. maculata with L. aristata, for instance Hennig (1941) and Soós (1982) who studied the types in the collection of Rondani. Later, however, Soós (1984) treated L. maculata as a good species with L. atriceps Bigot, 1886, and L. yerburyi Austen, 1899, as synonyms. This concept was adopted by Schacht (1996) for Bavaria, van der Goot \& van Veen (1996) for the Netherlands and Merz et al. (2002) for Switzerland. On the other hand, Barták \& Carles-Tolrá (2006) in the Catalogue of Diptera of Czech and Slovak Republics listed L. maculata as subspecies of L. aristata.

L. atriceps, considered to be a synonym of L. maculata by Soós (1984), is now believed to be a variety of L. aristata differing only in its colouration.

The Swiss specimens of L. maculata differ from those of other countries. They are characterized by a rather short postpedicel which is shorter than the length of the frons (measured from the posterior ocelli to the lunule), by a long arista which is longer than the postpedicel, and by an entirely black thorax (Figs P1, P2).

In external characters L. maculata differs from L. aristata by its almost black thorax including the scutellum. On the other hand, no clear differences in the structure of the male terminalia have yet been found. Therefore, additional specimens from various localities are necessary in order to clarify the taxonomy of the two taxa. For the time being they are treated as distinct species.

Subgenus Platystyla Macquart, 1835

TYPE SPECIES: Loxocera hoffmannseggi Meigen, 1826, by monotypy.

COMMENTS: In the current interpretation the subgenus contains five species, four of which are recorded from the East Palaearctic Region (Russian Far East, Japan, China). One species occurs in Europe.

\section{Loxocera (Platystyla) hoffmannseggi Meigen, 1826}

Material Switzerland: 10 . Bern, Kirchenfeld, 19 VIII 1924, leg. Th. Steck. - 10 , ZH, 410 m, Embrach-Haumüli, 20 VIII 1997, leg. B. Merz.

Genus Imantimyia Frey, 1925

TYPE SPECIES: Nemotelus albiseta Schrank, 1803, by original designation. 

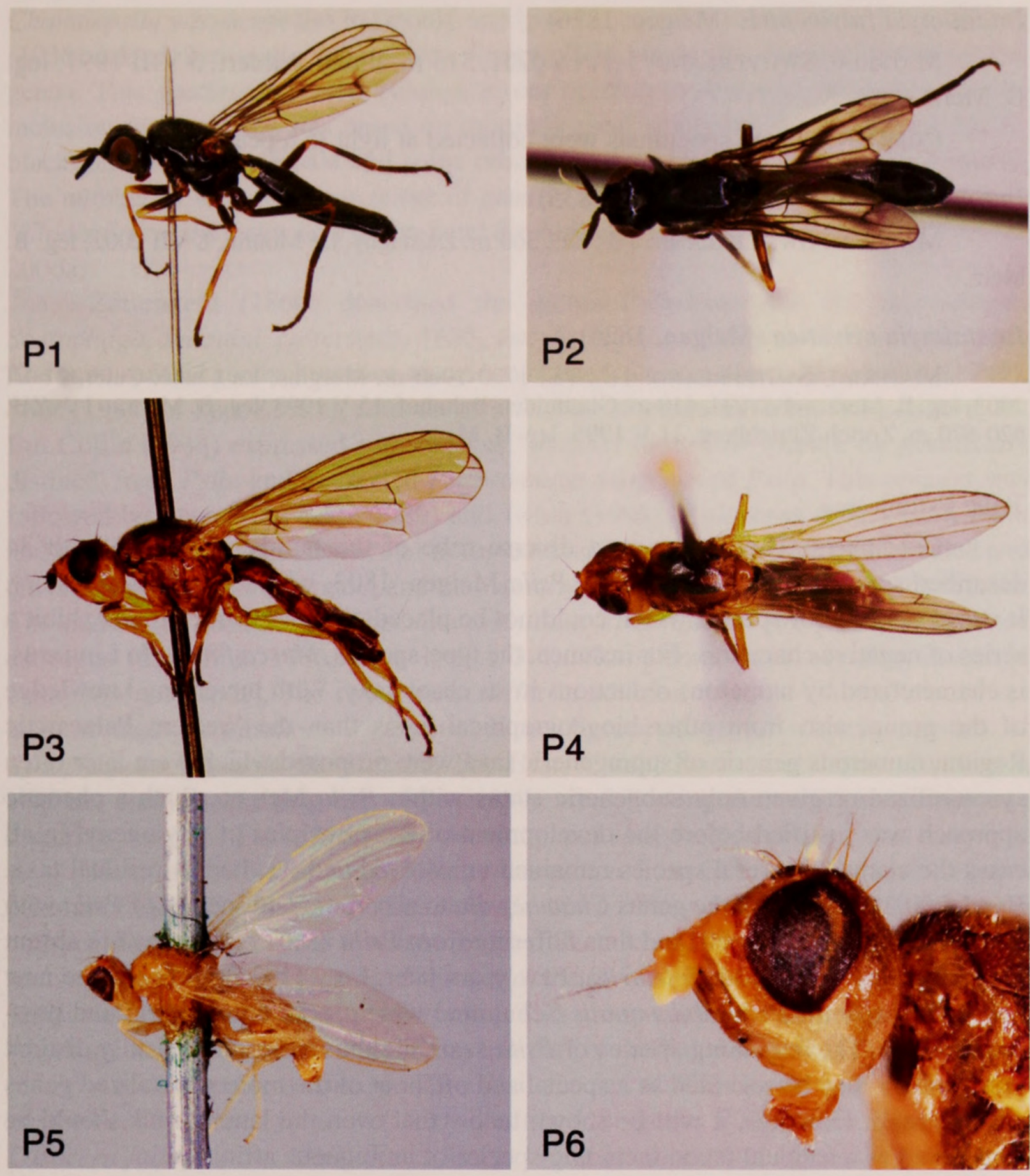

\section{P4}

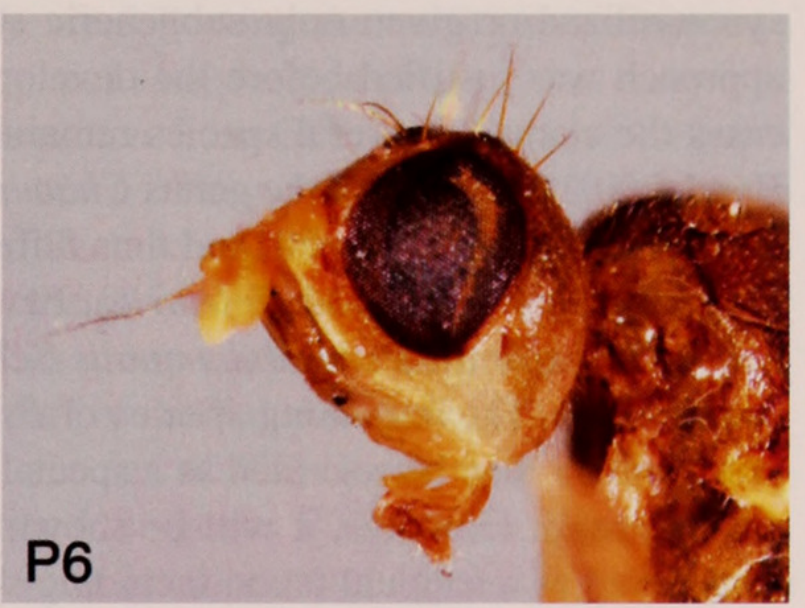

\section{PLATE 1-6}

Habitus and details of Psilidae. (P1, P2) Loxocera maculata Rondani, habitus lateral and dorsal (CH, VS, 2000 m, Simplon/Hospiz, 645450/121680, 4 VII 2001). (P3, P4) Psila helvetica sp. $\mathrm{n}$. (holotype, CH, VS, 650 m, Leuk-Pfynwald, 23 IX 1992). (P5) Chamaepsila pallida (Fallén) (male syntype, probably from Sweden, Esperöd, NRS). (P6) head of Ch. pallida (female syntype, probably from Sweden, Esperöd, NRS).

COMMENTS: The European fauna contains four species which are all known from Switzerland.

Imantimyia albiseta (Schrank, 1803)

Material Switzerland: $4 \%$, GE, 420 m, Bernex, Bois des Mouilles, 19 VIII 2006, leg. B. Merz. - 1 \& , SG, 910 m, Unterwasser, 15 VIII 1997, leg. B. Merz. - 1 0 , ZH, 450 m, ZürichAllmend, 10 IX 1996, leg. B. Merz. 
Imantimyia fulviventris (Meigen, 1826)

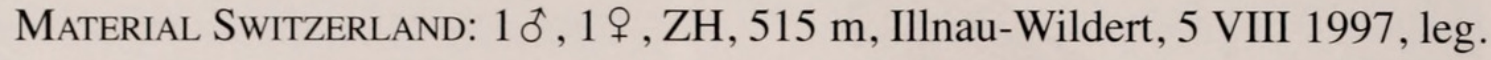
B. Merz.

COMMENTS: Both specimens were collected at light in a peat-bog.

Imantimyia nigrifrons (Macquart, 1835)

Material Switzerland: $1 \delta^{\Uparrow}$, GE, 360 m, Dardagny, Le Moulin, 8 VII 2002, leg. B. Merz.

\section{Imantimyia sylvatica (Meigen, 1826)}

Material Switzerland: $10^{\star}$, VS, 1700-1900 m, Morgins, La Chaux-Culet, 21 VI 2003, leg. B. Merz. - 1 đै, ZH, 410 m, Glattfelden-Bahnhof, 15 V 1993, leg. B. Merz. - 1 क , ZH, 620-670 m, Zürich-Zürichberg, 11 V 1995, leg. B. Merz.

\section{Tribe Psilini}

COMMENTS: This is the most diverse tribe of the family in Europe with 34 described species. It includes notably Psila Meigen, 1803, with its confusing history. It was described for species which could not be placed elsewhere and which exhibit a series of negative characters. For instance, the type-species, Musca fimetaria Linnaeus, is characterized by numerous reductions in its chaetotaxy. With increasing knowledge of the group, also from other biogeographical areas than the Western Palaearctic Region, numerous generic or suprageneric taxa were proposed which were later often synonymized or given only subgeneric status within Psila Meigen. Such a phenetic approach was justified before the development of the principles of phylogeny. In all cases the status of several species remained unresolved and resulted in residual taxa. Hendel (1917) described the genus Chamaepsila to accommodate species of Psila with postocellar setae developed, and thus differing from Psila s. str. where they are absent (e. g., the type-species M. fimetaria). Few years later, Frey (1925) proposed the new genus Oxypsila for Psila abdominalis Schummel which lacks dorsocentral and postocellar setae. The remaining species of Psila s. str. are thus a morphologically distinct group which may be regarded as a specialized offshoot of the more generalized genus Chamaepsila. However, it will be shown below that even the latter genus should be considered as a residual taxon including species of ambiguous affinities.

Hendel (1934) described the genus Synaphopsila for one Chinese species, $S$. hummeli Hendel, 1934, which is characterized by the presence of three vertical setae instead of two setae present in Oxypsila. Later, Wang \& Yang (1996) synonymized the two genera and included $S$. hummeli and three new Chinese species in Oxypsila. While studying $S$. hummeli, new differences compared with $P$. abdominalis were found, like the absence of notopleural setae (as it is also the case in Psilosoma Zetterstedt, but one notopleural seta is present in P. abdominalis). There are evidences that $S$. hummeli (and further 9 East Palaearctic species of the same group) does not form a monophylum with P. abdominalis. Synaphopsila is probably closer related to Psila s. str. and therefore considered here to be a subgenus of the latter.

Frey (1925) proposed the genus Tetrapsila for Psila obscuritarsis Loew, 1856, a species with four scutellar setae (two pairs), which was formerly placed in 
Chamaepsila whose species have only one (pair of) apical scutellar setae. Later, Séguy (1936) added Tetrapsila longipennis Séguy, 1936, from the Açores Islands to the genus. This species, however, belongs in our opinion to Afropsila Shatalkin, and its inclusion in Tetrapsila was based on morphological similarity. It is characterized by black halteres in the female and some other features which are typical for Afropsila. The number of scutellar setae is not of generic value, as two pairs are also present in "Chyliza" gracilis Loew (see below) and the Asian Xenopsila Buck (Buck \& Marshall, 2006a).

Zetterstedt (1860) described the genus Psilosoma for the two species Scatophaga audouini Zetterstedt, 1835, and Scatophaga lefebvrei Zetterstedt, 1835. The status of this genus, however, is not established. Some authors, like Hennig (1941), Soós (1984) or Pape (2007), considered it as a good genus different from Psila s. lat. But Collin (1944) expressed some doubts "whether these two species are generically distinct" from Psila and he treated Psilosoma as subgenus of Psila. This opinion was followed by Shatalkin $(1986,1989)$ and Iwasa (1998). Psilosoma differs from Psila and Chamaepsila by the absence of notopleural and supra-alar setae, the expanded and curved hind femur in the male, and the laterally compressed ovipositor in the female. The male terminalia are also peculiar with their long, dilated and poorly sclerotized aedeagus (Shatalkin, 1986, plate 1, figs 3-4). Notopleural setae are also absent in Synaphopsila Hendel. The two genera differ in addition to some external characters also in their distribution. Psilosoma is an European genus whereas species of Synaphopsila occur in the Russian Far East, China, Korea and Japan. Pending a cladistic analysis of this group of genera we are following the tradition of European dipterists and treat Psilosoma in the present paper as a good genus.

Hennig (1941) described Psila problematica from Germany. However, a comparison of its type with that of Chamaepsila sibirica Frey, 1925, showed that they are conspecific and they were synonymized by Shatalkin (1986). He proposed for this species a new subgenus in Psila, Freyopsila Shatalkin, 1986, in order to accommodate species of Psila without postocellar setae. This group contains currently eight species which are mainly distributed in the Eastern part of the Palaearctic Region.

Another problem concerns American species of Psila s. lat. with an elongated postpedicel for which Johnson (1920) described the genus Pseudopsila (type species: Loxocera fallax Loew, 1869). Later, Frey (1955) described two Oriental species from Myanmar (Pseudopsila maculipennis and P. nigricollis) and Shatalkin (1983) added the first Palaearctic species to the genus ( $P$. nigrifulva). A careful study of the types of the two species described by Frey and the Nearctic Pseudopsila collaris (Loew, 1869) and $P$. lateralis (Loew, 1860) revealed that $P$. nigrifulva does not belong to this genus but seems to be closer related to Psila sibirica (Frey), and it was transferred to Freyopsila (Shatalkin, 1983). More recently, Buck \& Marshall (2006a) revised the Nearctic species of Pseudopsila and concluded based on a cladistic analysis that the type species of Pseudopsila (L.fallax), as well as two other species, should be synonymized with Psila s. str. and proposed Xenopsila as new subgenus of Psila for the other Nearctic species previously placed in Pseudopsila ( $P$. bivittata, P. collaris, $P$. lateralis) as well as for the Oriental and Palaearctic species $(P .(X$.$) arbustorum$ Shatalkin, $P$. (X.) nemoralis Shatalkin, $P$. (X.) tetrachaeta Shatalkin). 
Among European Psila s. lat. a short comment should be made for Chyliza gracilis Loew, 1854, which is characterized by a long, finely setulose, white arista. Freidberg \& Shatalkin (2009) presented a review of its confusing taxonomic history. After a careful study of six specimens from Cyprus, Israel and Turkey they concluded that this species should be transferred in Chamaepsila thus becoming a junior homonym of Psila gracilis Meigen, 1826 which is now considered to be a synonym of Chamaepsila buccata (Fallén, 1826). Therefore, they proposed the replacement name Chamaepsila setalba Freidberg \& Shatalkin, 2009 for Chyliza gracilis Loew, 1854. However, its combination of characters differs from other species of Chamaepsila and it represents probably a separate lineage within the genus. Moreover, a single female from Bulgaria (Sandanski) differs in some points from Ch. setalba and may represent another yet undescribed species. Therefore, further studies based on more specimens are needed in order to propose well-funded arguments for the generic position and for the intra-specific variability of the included taxa.

A long-lasting debate is dividing students of the family Psilidae. Whereas some authors consider the various taxa of Psila s. lat. as valid genera (Hennig, 1941; Soós, 1984; Pape, 2007), others treat them as subgenera of Psila s. lat. (Shatalkin, 1989, 2008; Iwasa, 1998). Based on a morphological analysis of external characters alone this question cannot be resolved. The differences ("gaps") between the taxa are weightened in a different manner by each student, and apparently "good" characters in one biogeographical region may be unreliable in other areas because of intermediate species or species-groups. For instance, the Non-European taxon Xenopsila described as subgenus of Psila (Buck \& Marshall, 2006a) is characterized by a most peculiar type of male terminalia with a long, thin, scerotized aedeagus. But some species of Loxocera, in particular the L. (Imantimyia) achaeta group (including the Nearctic species L. cylindrica Say, L. fumipennis Coquillett, L. ignyodactyla Buck, the Japanese L. lutulenta Iwasa and the Palaearctic L. achaeta Shatalkin and L. nigrifrons Macquart) are similar and overlap with those of Xenopsila.

Species of Freyopsila, Psilosoma, Synaphopsila and (Chamaepsila + Psila) form a group which is characterized by a similar, more simple structure of male terminalia. Male terminalia of Psila s. str. and Chamaepsila resemble each other and are clearly separated from the other genera and represent a third level of the structure of the male terminalia. If only European species of the two taxa are considered then they form clearly two distinct groups which would deserve generic rank. However, with the inclusion of Asian species differences between them become unreliable because of species with an intermediate combination of characters. For this reason Iwasa (1998) treated Chamaepsila as a subgenus of Psila s. lat. It is therefore not surprising that the Japanese species Psila magna (Shatalkin, 1983) was described as Chamaepsila because it has a well developed postocellar seta as it is the case for other Chamaepsila. On the other hand, Psila nigripalpis Shatalkin, 1983, is similar to some species of Chamaepsila, in particular of the Ch. rufa group, but lacks the postocellar setae and was described originally in Psila.

Based on these problems all available species of the two taxa were studied again in detail in order to redefine their generic placements. It was found that a new character, the presence of fine, inconspicuous setulae on the posterior half of the 
anepimeron, is a constant character for species of Psila s. str. Such setulae are absent in all species of Chamaepsila (except for one species, Chamaepsila fenestralis Shatalkin, 1983, from Russian Far East) and other taxa of Psila s. lat. For this reason we propose here to treat Chamaepsila and Psilosoma as distinct genera and exclude them from Psila s. str. Some characters which were found to be of diagnostic value for the various taxa of Psila s. lat. are summarized in Tab. 1.

TAB. 1. Diagnostic characters of Psila s. lat. In ( ): exceptions, see species listed below

\begin{tabular}{|c|c|c|c|c|c|c|c|c|}
\hline Characters & 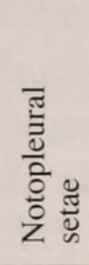 & 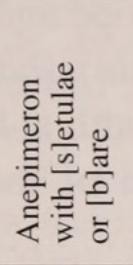 & 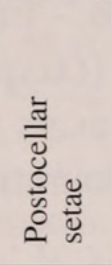 & 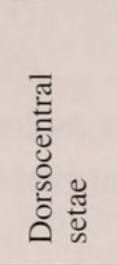 & 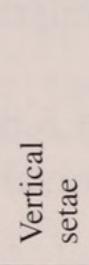 & 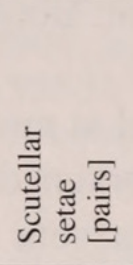 & 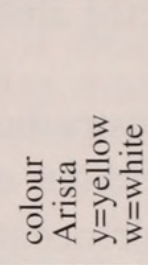 & 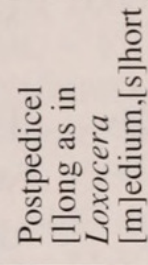 \\
\hline Psila s. str. spp. & 1 & (b), $\mathrm{s}$ & 0,1 & $(0), 1$ & $2-3$ & 1 & (w), y & $(\mathrm{m}), \mathrm{s}$ \\
\hline P. abdominalis & 1 & $\mathrm{~S}$ & 0 & 0 & 2 & 1 & $\mathrm{y}$ & S \\
\hline P. crassula, $P$. magna & 1 & $\mathrm{~s}$ & 1 & 1 & 2 & 1 & $\mathrm{y}$ & $\mathrm{s}$ \\
\hline P. fallax & 1 & $\mathrm{~b}$ & 1 & 1 & 2 & 1 & W & $\mathrm{m}$ \\
\hline Chamaepsila spp. & 1 & $\mathrm{~b},(\mathrm{~s})$ & 1 & $1-4$ & $2-3$ & $1-2$ & (w), y & $(\mathrm{m}), \mathrm{s}$ \\
\hline Ch.fenestralis & 1 & $\mathrm{~S}$ & 1 & 1 & 2 & 1 & $\mathrm{y}$ & $\mathrm{S}$ \\
\hline Ch. obscuritarsis & 1 & $\mathrm{~b}$ & 1 & 1 & 3 & 2 & $\mathrm{y}$ & $\mathrm{s}$ \\
\hline Ch. setalba & 1 & $\mathrm{~b}$ & 1 & 1 & 2 & $1-2$ & W & $\mathrm{m}$ \\
\hline Afropsila spp. & 1 & $\mathrm{~b}$ & 0 & 1 & 2 & $1-2$ & W & $\mathrm{s}$ \\
\hline Asiopsila spp. & 1 & $\mathrm{~b}$ & $0-1$ & $0-1$ & 2 & 2 & w & 1 \\
\hline Freyopsila spp. & 1 & $\mathrm{~b}$ & $0,(1)$ & 1 & 2 & 1 & $\mathrm{y}$ & $1,(\mathrm{~m}), \mathrm{s}$ \\
\hline F. maculipennis group & 1 & $\mathrm{~b}$ & 1 & 1 & 2 & 1 & w & $\mathrm{m}$ \\
\hline Psilosoma spp. & 0 & $\mathrm{~b}$ & 0 & $0-1$ & 2 & 1 & $\mathrm{y}$ & $\mathrm{S}$ \\
\hline Synaphopsila spp. & 0 & $\mathrm{~b}$ & 0 & $0-1$ & $2-3$ & 1 & W & $\mathrm{s}$ \\
\hline Xenopsila spp. & 1 & $\mathrm{~b}$ & 1 & 1 & 2 & 2 & w & $\mathrm{m}, \mathrm{s}$ \\
\hline
\end{tabular}

\section{Genus Psila Meigen, 1803}

TYPE SPECIES: Musca fimetaria Linnaeus, 1761, by subsequent designation of Westwood, 1840: 146.

DiAGNOSIs: Head large, yellow. Postocellar setae absent (present in some Chinese and Japanese species). Two vertical setae (three in some Chinese species). Mesonotum with one dorsocentral seta (absent in P. abdominalis). Scutellum with one (pair of) seta and with soft, scattered, marginal setulae. Anepimeron with soft, fine setulae in posterior half (also present in Chamaepsila fenestralis Shatalkin, 1983; this species and Ch. bimaculata Shatalkin, 1983, form an isolated group related to Psila s. str.).

Distribution: Psila s. str. may be a comparatively young genus. It has a disjunct distribution in the Palaearctic Region with five West Palaearctic species, one species from the Kuril Islands and Japan (P. magna Shatalkin), and some species from the mountains of Western China.

Key to EUROPEAN SPECIES OF PSILA S. STR.

1a Anepimeron with soft, fine setulae in posterior half; postocellar setae absent (except for some Asian species); tarsus of mid leg ventrally with short, black setulae scattered among the golden setulae ......Psila s. str. 2 
1b Anepimeron bare; one postocellar seta present (except for most specimens of Ch. setalba Freidberg \& Shatalkin and the East Palaearctic species Ch. nigripalpis); tarsus of mid leg ventrally with short yellow

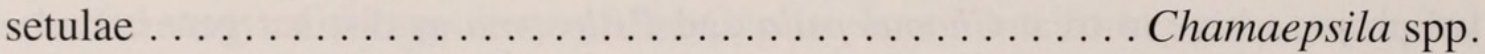

2a Postpedicel about 2.5 times as long as its width at base, yellow but dark infuscated along dorsal margin; abdomen brownish to black; thorax yellow or reddish yellow with a darker stripe laterally the level of the supra-alar seta and the dorsal half of the anepisternum; dorsocentral setae absent. Body length: 6-1-7.3 mm. - Europe and Caucasus . . . . . . .

Psila (Oxypsila) abdominalis Schummel, 1844

2b Postpedicel at most 1.5 times as long as its width at base, if yellow then without darkened dorsal margin; colouration of thorax different; one

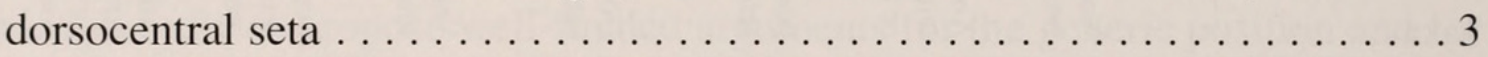

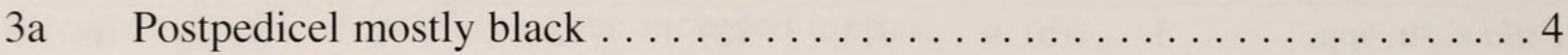

3b Postpedicel yellow, at most at base of arista with darkened spot . . . . . . 5

4a Mesonotum and subscutellum yellow. Body length: 6.7-7.2 mm. Caucasus . . . . . . . . . . . . . . Psila (s. str.) caucasica Mik, 1887

4b Mesonotum yellow, but with an unpaired black stripe medially extended almost to scutellum, and with a pair of black stripes from posterior end of postpronotal lobe to level of dorsocentral seta (sometimes these black stripes may be confluent). Subscutellum black. Body length: 6.5$7.0 \mathrm{~mm}$. - Switzerland . . . . . . . . . . . Psila (s. str.) helvetica sp. n.

5a Eye kidney-shaped, distinctly higher than wide; postpedicel at base of arista with black spot; rays of arista about twice as long as its basal diameter. Body length: 7.7-8.8 mm. - Europe . . . . . . . . . . . . .

Psila (s. str.) fimetaria (Linnaeus, 1761)

5b Eye roundish, only slightly higher than wide; postpedicel entirely yellow; rays of arista at most only little longer than its basal diameter. Body length: 8.3-8.5 mm - Europe . . . . . Psila (s. str.) merdaria Collin, 1944

\section{Subgenus Oxypsila Frey, 1925}

TYPE SPECIES: Psila abdominalis Schummel, 1844, by monotypy.

\section{Psila (Oxypsila) abdominalis Schummel, 1844}

Material Switzerland: 10 , VS, 640 m, Raron, 14 VII 1966, leg. L. \& F. Keiser. $-1 q$, VS, 623 m, Leuk-Platten, 3 VIII 1998, leg. Merz \& Bächli.

COMmENTs: Wang \& Yang (1996) described three species from China without postocellar and dorsocentral setae as Oxypsila (O. altusfronsa, O. nigricorpa, O. unistripeda), but without indication of the presence of the soft, fine setulae on the anepimeron which are characteristic for $P$. abdominalis and allow its placement in Psila s. str. (see diagnosis above). Because they were not available for examination their generic placement remains tentative.

P. abdominalis may be found in mountains of Central and Southern Europe. It is unknown from the British Isles (Collin, 1944; Chandler, 1998a), Holland (van der Goot \& van Veen, 1996) and Scandinavia. Its northern border passes across Germany, 
Czech and Slovak Republics, Hungary, and the Caucasus in the East. One specimen, however, was recently caught in the Moscow Region. It may therefore have a larger distribution than the few specimens of this rather rarely collected species in the museum collections indicate.

Subgenus $\boldsymbol{P}$ sila Meigen, 1803

\section{Psila (s. str.) fimetaria (Linnaeus, 1761)}

Material Switzerland: 2 , BE, 1300 m, Zweisimmen, Gschwänd, 7 VI 2003, leg. B. Merz \& M. Eggenberger. - 1 , GE, 390-430 m, Dardagny, rivière de Roulave, 11 VIII 2000, leg. Merz \& Bächli. - 1 ठे, GE, Avusy, Moulin de la Grave, 25 V 2006, leg. H. Boillat. - 1 \%, GR, 1325 m, Ausserferrera, 30 VIII 2006, leg. B. Merz. - 1 \% , GR, 1300-1670 m, AusserferreraCresta, 1 IX 2006, leg. B. Merz. - 2 \% , JU, 1000 m, La-Chaux-des-Breuleux, La Tourbière, 28 VI 2003, leg. B. Merz. - 1 \%, SG, 910 m, Unterwasser, 11 VII 1997, B. Merz. - 2 q, VS, 19002200 m, Visperterminen, Giw-Gebidempass, 21 VII 2004, leg. B. Merz. - 1 9 , VS, 1400 m, Visperterminen, Kreuz, 3 VI 2003, leg. B. Merz. - 1 \% , VS, 1300 m, Morgins-En Tey, 22 VI 2003, leg. B. Merz. - 1 q , ZH, 400 m, Embrach-Haumüli, 24 VI 1995, leg. R. Wunderlin.

Comments: This is one of the most common species of the family in Switzerland and may be found in various habitats from the lowlands to about $2200 \mathrm{~m}$ in the Alps.

Psila (s. str.) helvetica sp. n.

Figs P3-P4 (MHNG).

Holotype: §, Switzerland, VS, 650 m, Leuk-Pfynwald, 23 IX 1992, leg. Merz \& Otto

PARATYPES: $1 q$, same data as holotype (MHNG). $-1 \%$, Switzerland, GR, 670-1100 m, Flims/Bergsturz, 13 IX 1993, leg. B. Merz (MHNG).

Diagnosis: P. helvetica differs from other European species of Psila s. str. by the three black stripes on the mesonotum, the black subscutellum, the mostly black postpedicel, and the short, fine rays on the arista. This combination of characters is unique and P. helvetica occupies an isolated position in the genus (Figs P3, P4).

\section{DESCRIPTION MALE}

Measurements $(\mathrm{n}=1)$ : Body length: $6.8 \mathrm{~mm}$; wing length: $6.0 \mathrm{~mm}$.

Head: Ground colour yellow. Ocellar triangle blackish. Antenna yellow, but postpedicel mostly black, 1.2 times as long as wide at base. Arista brown, conspicuously thickened at base, covered with short, thin rays. Eye roundish, small in profile compared to gena and parafacialia. Gena about 1.2 times higher than height of eye. Compound eye about 1.5 times higher than long. Width of frons about 1.1 times less than its length from the two posterior ocelli to the lunule. Width of frons about 1.8 times less than width of head. Frons uniformly yellow. Gena about 1.3-1.4 times less high than eye. Palpus yellow, black apically. Chaetotaxy (all setae black): 2 vertical setae; 1 fronto-orbital seta (?), postocellar seta absent.

Thorax: Ground colour yellow. Mesonotum with a broad, black stripe medially extending almost to scutellum. A pair of lateral black stripes from level of hind margin of the postpronotal lobe to level of dorsocentral seta. These lateral stripes may fuse partly with the unpaired medial stripe or be interrupted on level of suture. Subscutellum black. Anepimeron with fine, soft setulae in posterior half. Chaetotaxy (all setae black): 1 notopleural seta; 1 supra-alar seta; 1 postalar seta; 1 dorsocentral seta; 1 (pair of) apical scutellar seta, without soft, fine setulae along the margin. 
Legs: Generally yellow. Middle tibia with two black apical spur-like setae of unequal size.

Wing: Entirely hyaline, with a slight yellowish tinge. Veins yellow. Section of M1+2 between R-M and DM-Cu about 1.5 times as long as previous section and subequal with apical section (between DM-Cu and margin). Haltere yellow.

Abdomen: Basal tergites black, other parts yellow. Terminalia not dissected.

Female

Measurements $(\mathrm{n}=2)$ : Body length: $6.5-7.0 \mathrm{~mm}$; wing length: $7.0 \mathrm{~mm}$.

Comments: Otherwise as male. Terminalia not studied.

\section{Psila (s. str.) merdaria Collin, 1944}

Material Switzerland: 19 , GR, 1550 m, 3 km N Lenz, 11 VII 1996, leg. B. Merz. 1 §., TG, 460 m, Ermatingen, Neuguet, 1 V 2002, leg. K. Grimm. - 1 q, ZH, 440 m, ZürichKatzensee, 25 V 1996, leg. B. Merz.

Comments: This species is morphologically similar to P. fimetaria and it is often difficult to separate them. It is a rather rare species which was described from Great Britain. Since then, it has been recorded from various Central European countries to the Moscow Region in the East and to Spain in the South (Pape, 2007; unpublished observations).

\section{Genus Psilosoma Zetterstedt, 1860}

TYPE SPECIES: Scatophaga audouini Zetterstedt, 1835, by original designation.

Diagnosis: Two vertical setae. Postocellar seta absent. Notopleural seta absent. Dorsocentral seta present or absent. 1 (pair of) apical scutellar seta. Anepimeron bare. Hind femur in male (and also in the female of P. audouini) thickened. Male terminalia with long aedeagus. Female ovipositor compressed laterally and strongly sclerotized.

Distribution: Two Western Palaearctic species are placed here which are distributed in cooler regions from Northern Scandinavia southwards to the Alps where they are usually found in higher altitudes. Both species are not uncommon in Switzerland in higher altitudes of the Alps where they may be often swept and observed on large stands of Alnus viridis.

Psilosoma audouini (Zetterstedt, 1835)

Material Switzerland: 1 ô, 19 , VS, 1600-2200 m, Visperterminen, Giw-Gebidem, 4 VII 2003, leg. B. Merz, J. Smit \& M. van Det. - 1 क , VS, 1900-2200 m, Visperterminen, GiwGebidempass, 21 VII 2004, leg. B. Merz.

Psilosoma lefebvrei (Zetterstedt, 1835)

Material Switzerland: 1 ô, GR, 2400 m, Lenzerheide, Piz Danis, 8 VIII 1992, leg. B. Merz. - $1 \delta^{\star}$, GR, 1500 m, Valbella-Casoja, 20 VII 1996, leg. B. Merz. - 10े, GR, 2200 m, Ftan, Clünas, 5 VIII 1996, leg. Merz \& Bächli. - 1 9 , GR, 1300 m, Ausserferrera, 13 VIII 1991, leg. Merz \& Freidberg. -1 \% , SZ, 1550 m, Pragelpass, 7 VIII 1995, leg. B. Merz.

Genus Chamaepsila Hendel, 1917

TyPE SPECIES: Musca rosae Fabricius, 1794, by original designation. 
DiagnOSIS: Arista yellow or slightly brownish, white only in Ch. setalba Freidberg \& Shatalkin (other species with a white arista are excluded from this genus: Psila fallax, Xenopsila spp.); postocellar seta present (usually absent in Ch. setalba); 2-3 vertical setae; 1-6 dorsocentral setae; 1 notopleural seta; 1 (pair of) apical scutellar seta (except for Ch. obscuritarsis with 2 pairs); anepimeron entirely bare (except for Ch. fenestralis from the Russian Far East).

COMMENTS: Steyskal (1987) did not recognize this genus in his key to genera and subgenera of Nearctic Psilidae. One reason may be that Psila s. str. was not yet known from that region and he considered the subgeneric division of Hennig (1941) as less convincing. However, taking into account the observations during the present study and the results of the work of Buck \& Marshall (2006a) this division is based on unequivocal characters which allow its safe identification (see key above).

\section{Chamaepsila atra (Meigen, 1826)}

Material Switzerland: 20 , BE, 1430 m, Lenk, Simmenfälle, 31 V 2003, leg. B. Merz \& M. Eggenberger. - 1 , BE, 995 m, Tramelan, La Tourbière, 4 VI 2003, leg. B. Merz, J.-P. Haenni \& M. Rapp. - 1 0 , GR, 2200-2550 m, Juf-Stallerberg, 19 VI 1994, leg. B. Merz. - $1 \delta^{\text {, }}$ GR, 2250-2490 m, Lenzerheide, Piz Danis, 12 VII 1996, leg. B. Merz. - 1ठ, GR, 1500 m, Valbella, Casoja, 19 VII 1997, leg. B. Merz. - 1 q, TI, 1965 m, Piora, 11 VI 1996, leg. M. Bernasconi. - 10, 2 \%, VS, 1700-1900 m, Morgins, La Chaux-Culet, 21 VI 2003, leg. B. Merz. - 1ठ, 1 ․ VS, 1700-1950 m, Morgins, Portes du Soleil (Monthey), 22 VI 2003, leg. B. Merz. 1 ô, VS, 1400 m, Visperterminen, Kreuz, 3 VI 2003, leg. B. Merz.

COMmEnTs: This Transpalaearctic species is characterized by the presence of 4 dorsocentral setae, this character only shared with Ch. clunalis (Collin, 1944) in the Western Palaearctic Region. Ch. clunalis was described from Great Britain and was later found in Central Europe and Spain but is still unknown from Switzerland (Pape, 2007). It differs from $C h$. atra by its larger epandrium in the male which gives the impression that the abdomen is parallel-sided (in Ch. atra more cone-like). Moreover, the posteroventral margin of the epandrium is extended into a tooth-like projection (Shatalkin, 1986, plate 4, fig. 9) (evenly rounded in Ch. atra). Finally, the female of $C$. clunalis has therefore a wider 7 th tergite which is as wide as the previous one (decreasing in width in $C$. atra). C. clunalis exhibits a wide variation in colouration, varying from black to brown, especially on the head.

\section{Chamaepsila bicolor (Meigen, 1826)}

Material Switzerland: 10े, GR, 2100 m, Ftan-Clünas, 5 VIII 1996, leg. B. Merz \& G. Bächli. - 1 § , GR, 1660 m, S Chanf-Flin, 7 VIII 1996, leg. B. Merz \& G. Bächli. - 1 \&, VS, 1550 m, Jeitzinen, 26 VI 1999, leg. B. Merz \& M. Eggenberger. - 20, VS, 1700-1900 m, Morgins, La Chaux-Culet, 21 VI 2003, leg. B. Merz. - 26, VS, 2040 m, Morgins, Pointe de Bellevue, 21 VI 2003, leg. B. Merz. - 1 \%, VS, 1390 m, Visperterminen/Kreuz, 3 VII 2003, leg. B. Merz, J. Smit \& M. van Det.

COMMENTS: The specimens from "Pointe de Bellevue" are characterized by the brown stripe on the pleura and fit therefore the description of Ch. nigromaculata (Strobl, 1909). The two species were later synonymized (Carles-Tolrá, 1993a). The males from Switzerland correspond well with the illustration of the lectotype of $\mathrm{Ch}$. $\mathrm{bi}$ color with the medially directed teeth on the epandrium (Soós, 1985, fig. 1A). On the other hand, the structure of the paramere without the tooth on the protuberance (see 
Carles-Tolrá, 1993a, fig. 6) is more similar to C. quadrilineata (Strobl, 1898). Further studies are necessary in order to establish the identity of these Swiss specimens.

\section{Chamaepsila buccata (Fallén, 1826)}

Psila gracilis Meigen, 1826; synonymy by Soós (1985).

Material Switzerland: 19 , GR, 680 m, Rothenbrunnen, 8 VIII 1996, leg. B. Merz \& G. Bächli. - 1ठ , 1 ㅇ, VS, 750 m, Branson/Follatères, 29 III 2002, leg. B. Merz.

Comments: Chamaepsila buccata, Ch. sardoa (Rondani, 1876) and Ch. rozkosnyi Carles-Tolrá, 1993, form a morphologically uniform group. Ch. sardoa has an entirely black antenna (basal segments yellowish in Ch. buccata), 2 dorsocentral setae (1 dorsocentral seta in Ch. buccata), is on average smaller (3-4 mm, Ch. buccata 4-6 mm) and differs in the structure of the male terminalia (Shatalkin, 1986, plate 2, fig. 5 for Ch. buccata (as Ch. gracilis Meigen) and plate 3, fig. 1 for Ch. sardoa). Ch. rozkosnyi is characterized by the presence of 2 fronto-orbital setae ( 1 fronto-orbital seta in Ch. buccata and Ch. sardoa) and in details of the structure of the male terminalia with a longer aedeagus (Carles-Tolrá, 1993b).

Chamaepsila buccata has a transpalaearctic distribution. Outside Europe it is reported from Mongolia (Soós, 1974), China (Wang \& Yang, 1996), and the Russian Far East (Shatalkin, 1986).

Chamaepsila confusa sp. $\mathrm{n}$.

Fig. 1

HolotyPE: ô, CH (=Switzerland), VS, 600 m, Leuk-Pfynwald, 25 VIII 2001, leg. Merz \& Landry (MHNG).

PARATYPES: $1 \hat{\delta}$, same data as holotype (MHNG). -19 , Switzerland, TI, $460 \mathrm{~m}$, Clivio, Arzo, 4 X 2003, LF [= Lichtfalle, = light trap], leg. H. Vicentini (MHNG). - 1 o , France, HauteSavoie (74), Pormenaz, 1700-2200 m, 8-31 VII 2003, MTA [Malaise-trap], leg. Castella \& Speight (MHNG).

DiAgNOSIS: Externally, this species is similar to Ch. persimilis (Wakerley) and Ch. nigricornis (Meigen). It shares with $C h$. persimilis the presence of a yellow spot dorsally the anterior spiracle, but differs in the apically black palpus and the entirely black postpedicel. Ch. nigricornis has an entirely black pleuron including the propleuron. The three species differ further in details of the male terminalia, in particular in the shape of the aedeagus and the epandrium.

DESCRIPTION MALE

Measurements $(\mathrm{n}=2)$ : Body length: $3.7 \mathrm{~mm}$; wing length: $3.9 \mathrm{~mm}$.

Head: General colour yellow but with black ocellar triangle and a pair of narrow, black stripes on the occiput from vertex (between medial vertical setae) to the occipital foramen. Scape and pedicel yellow, postpedicel black, about 1.3 times as long as basal width. Arista brownish, short setulose, longest rays shorter than diameter of arista at base. Frons about as long as wide. Gena (in paratype) about 1.2 times less high than height of compound eye. Compound eye about 1.4 times as high as wide. Palpus black apically. Chaetotaxy (all setae yellow): 3 vertical setae; 1 stout postocellar seta; 2 fronto-orbital setae.

Thorax: Almost entirely black, but with a yellow spot on propleuron dorsally of anterior spiracle. Chaetotaxy (all setae yellow): 1 notopleural seta; 1 supra-alar seta; 1 
postalar seta; 2 dorsocentral setae posterior suture; 1 (pair of) apical scutellar seta. Anepimeron bare.

Legs: Entirely yellow.

Wing: Hyaline with yellowish veins. Section of M1+2 between crossveins R-M and DM-Cu about three times as long as section between BM-Cu and R-M and subequal to section between $\mathrm{DM}-\mathrm{Cu}$ and wing margin. Haltere yellowish white.

Abdomen: Entirely black. Male terminalia as in fig. 1.

\section{FEMALE}

Measurements $(\mathrm{n}=2)$ : Body length: $4.2 \mathrm{~mm}$; wing length: $4.3 \mathrm{~mm}$.

Comments: Otherwise as male.

COMMENTS: The male terminalia are characteristic for Ch. confusa. The base of the aedeagus is convex (fig. 1), but concave in Ch. nigricornis (Lyneborg, 1964; Shtakel'berg, 1989; van der Goot \& van Veen, 1996). Ch. persimilis is characterized by a special type of the aedeagus which has a strong desclerotization at its base in the middle (figs 4-5).

\section{Chamaepsila humeralis (Zetterstedt, 1847)}

Material Switzerland: 1 q , BE, 650-950 m, Mt. Raimeux, Corcelles, 2 VI 2003, leg.

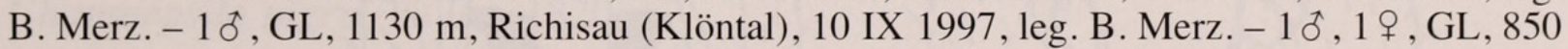
m, Vorauen (Klöntal), 10 IX 1997, leg. B. Merz. - 60, 7 오, GR, 1300-1670 m, AusserferreraCresta, 28 VIII-1 IX 2006, leg. B. Merz. - 1 q , GR, 980 m, Andeer (Hinterrhein), 29 VIII 2006, leg. B. Merz. - 20, GR, 1500 m, Valbella, Casoja, 21 VII 1997, leg. B. Merz. - 1 ㅇ. TI, 460 m, Clivio, Arzo, 4 X 2003, LF (= light trap), leg. H. Vicentini. - 1ô, VD, 1300 m, St.Cergue, Barillette, 3 VIII 2003, B. Merz. - 20, 1․ VS, 1300 m, Morgins, En Tey, 22 VI 2003, leg. B. Merz. - 1 q , VS, 1600-2200 m, Visperterminen, Giw-Gebidem, 4 VII 2003, leg. B. Merz, J. Smit \& M. van Det.

COMmEnTs: This species is well characterized by the presence of an entirely yellow postpronotal lobe and propleuron and thus differs from other species with mainly black thorax and the same chaetotaxy (Ch. confusa, Ch. nigricornis, Ch. persimilis, Ch. rosae). The Swiss specimens show a remarkable variability in the colour of the anepimeron. Whereas the anepimeron is usually black in this species, it is yellow in the specimens from Morgins. The male terminalia, however, are the same in both colour morphs and they are considered here to belong to the same species.

One male deserves a comment. It carries the following labels: "Helv., VD, 1300 m, St. Cergue, Barillette, 3 VIII 2003, leg. B. Merz". It differs from typical specimens of $C h$. humeralis by a black mesonotum with a yellow longitudinal stripe between the postpronotal lobe and the wing base, and on the dorsal half of the pleuron. The anepisternum is black in the posterior half and the anepimeron slightly brownish. The study of the male terminalia, however, does not show any difference and it is concluded that this specimen is an extreme colour form of $C h$. humeralis. A more detailed interpretation of the status of this colour morph can only be obtained by the study of additional specimens.

\section{Chamaepsila limbatella (Zetterstedt, 1847)}

Material Switzerland: 1 \% , GR, 2100 m, Ftan-Clünas, 5 VIII 1996, leg. B. Merz \& G. Bächli. - 1, GR, 1500 m, Valbella, Casoja, 19 VII 1997, leg. B. Merz. - 1 q, VS, 19002100 m, Visperterminen, Rothorn-Giw, 30 VII 1998, leg. B. Merz \& G. Bächli. 

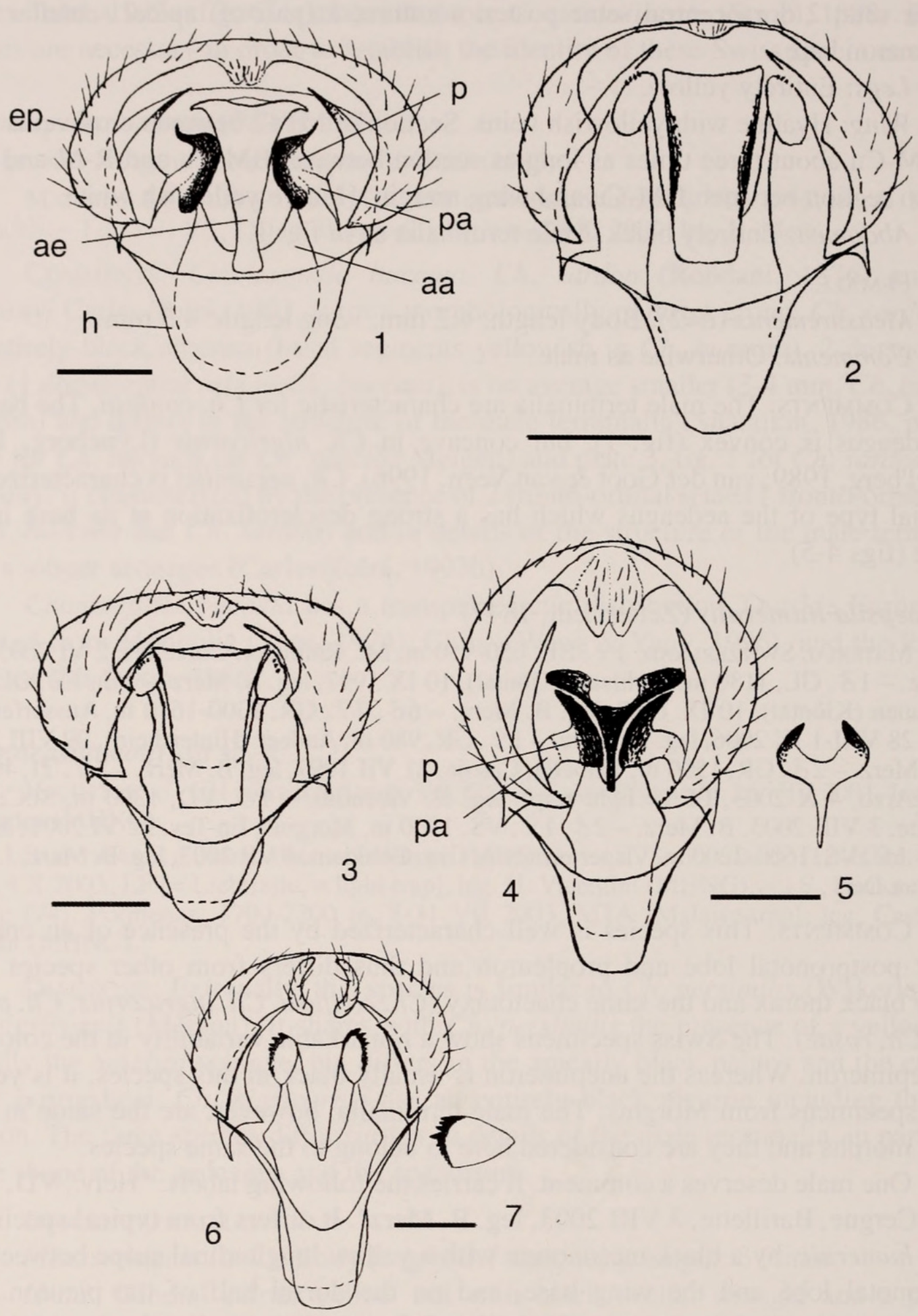

FIGS 1-7

Male terminalia of Chamaepsila spp. (1) Ch. confusa sp. n., ventral view (holotype, CH, VS, 600 m, Leuk-Pfynwald, 25 VIII 2001). (2) Ch. pallida (Fallén), ventral view (CH, BE, Mt. Raimeux, Corcelles, 2 VI 2003). (3) Ch. pallida (Fallén), ventral view (Russia, Moscow Region, Golitsyno, 23 VI 1981). (4) Ch. persimilis (Wakerley), ventral view (CH, VS, Eggerberg-Erb, 24 VI 2000). (5) Ch. persimilis (Wakerley), aedeagus (F, Haute Savoie, Monnetier, Petit Salève, 24 VIII 2003). (6) Ch. unilineata (Zetterstedt), ventral view (CH, TI, 1097 m, Mte. S. Giorgio, top, 18 V 2006). (7) Ch. unilineata (Zetterstedt), paramere, lateral view (same data).

Abbreviations: $a a=$ aedeagal apodeme; $a e=$ aedeagus; $e p=$ epandrium; $h=$ hypandrium; $p=$ paramere; $p a=$ parameral arm. 
Comments: This is a rare European species which is easy to identify with its black body and its chaetotaxy with 3 vertical setae, 1 fronto-orbital seta, and 1 dorsocentral seta (all pale).

\section{Chamaepsila morio (Zettestedt, 1835)}

Material Switzerland: 40ิ, 1 q, BE, 1430 m, Lenk, Simmenfälle, 31 V 2003, leg. B. Merz \& M. Eggenberger. - 10 , GR, 2250-2490 m, Lenzerheide, Piz Danis, 12 VII 1996, leg. B. Merz. -4 \& , GR, 1520 m, Lenzerheide/Sundroina, 17 V 1997, leg. B. Merz. - 1 \&, GR, 1490 m, Valbella, Casoja, 11 VII 1998, leg. B. Merz. - 2 , VS, 1700-1900 m, Morgins, La Chaux-Culet, 21 VI 2003, leg. B. Merz. - 1 0 , 1 क , VS, 1700-1950 m, Morgins, Portes du Soleil (Monthey), 22 VI 2003, leg. B. Merz. - 1 ㅇ, VS, 1900-2200 m, Visperterminen, Giw-Gebidempass, 21 VII 2004, leg. B. Merz. - 3 q , VS, 1600-2200 m, Visperterminen, Giw-Gebidem, 4 VII 2003, leg. B. Merz, J. Smit \& M. van Det. - 1 q, VS, 1400 m, Visperterminen/Kreuz, 3 VI 2003, leg. B. Merz. - 1 q, VS, 1300-1900 m, Visperterminen, Richtung Giw, 15 VII 1995, leg. B. Merz.

COMmEnTS: Chamaepsila morio is widespread in Scandinavia and Nothern Russia. In the South it is mainly known from higher altitudes of the Alps. In the Eastern parts of the Palaearctic Region it is recorded from the Altai Mountains, Yakutia and Magadan (but only females are known from the latter two localities). Soós (1974) identified this species from Mongolia based on three females.

\section{Chamaepsila nigra (Fallén, 1820)}

Material Switzerland: 1 q , GE, 350 m, Cartigny, Moulin de Vert, 22 IV 2000, leg. B. Merz. - 1 q, GR, 1550 m, Lenzerheide/Sundroina, 20 VII 1997, leg. B. Merz. - 19 , GR, 1500 m, Valbella, Casoja, 19 VII 1997, leg. B. Merz. - 1 q , VS, 1600-2200 m, Visperterminen, GiwGebidem, 4 VII 2003, leg. B. Merz, J. Smit \& M. van Det. - 1ô, 1 , VS, 1400 m, Visperterminen/Kreuz, 3 VI 2003, leg. B. Merz.

\section{Chamaepsila nigricornis (Meigen, 1826)}

Material Switzerland: $1 \%$, BE, 650-950 m, Mt. Raimeux, Corcelles, 2 VI 2003, leg. B. Merz. - 20े, GE, 420 m, Bernex, Bois de Carabot, 29 IV 2005, leg. B. Merz. - 2 q, GE, 510 m, Bernex-Signal, 24 IV 2003, leg. B. Merz \& F. Amiet. - 1 $\sigma^{\star}$, GE, 500 m, Bernex-Signal, 30 IV 2007, leg. B. Merz. - 1 q, GE, Avusy, Moulin de la Grave, 15 V 2003, leg. H. Boillat. 10 , GR, 1600 m, Lenzerheide/Sundroina, 16 VII 2000, leg. B. Merz. - 10 , 2 q , GR, 13001325 m, Ausserferrera, 28-30 VIII 2006, leg. B. Merz. - 1 \% , JU, 1000 m, Le Chaux, Les Breuleux, La Tourbière, 28 VI 2003, leg. B. Merz. - 1 ㅇ, TI, 370m, Cugnasco-Montedato, 2 IV 2007, B. Merz. - 1 ㅇ, TI, 205 m, Gordola, Verzascaufer, 1 IV 2007, leg. B. Merz. - 1 ㅇ, VS, 650 m, Baltschieder, Chumme, 23 V 1998, leg. B. Merz. - 10ิ, VS, 920 m, Leuk-Brentjong, 15 V 2000, leg. B. Merz. - 10 , VS, 625 m, Leuk-Platten, 2 V 1999, leg. B. Merz. - 1 q , VS, 1700$1900 \mathrm{~m}$, Morgins, La Chaux-Culet, 21 VI 2003, leg. B. Merz. - 20ิ, VS, $1550 \mathrm{~m}$, Visperterminen, ob Dorf, 27 VIII 2001, leg. B. Merz \& B. Landry. - 2 + , ZH, 430 m, ZürichAllmend, 6 V 1998, leg. B. Merz. - 1 , ZH, 630 m, Zürich-Zürichberg, 6 IX 1992, leg. B. Merz.

COMmENTs: Chamaepsila nigricornis is known as a pest of Chrysanthemum sp. with its larvae feeding in the roots (Vernon, 1962; Iwasa, 1998). Morphologically, it can be confused with Ch. confusa, Ch. persimilis, and Ch. rosae which have the same general body colouration and chaetotaxy. However, their male terminalia are different and allow an easy identification (Wakerley, 1959; Lyneborg, 1964; Wang, 1988; Shtakel'berg, 1989).

\section{Chamaepsila obscuritarsis (Loew, 1856)}

Material Switzerland: 10, ZH, $650 \mathrm{~m}$, Zürich-Zürichberg, 16-20 VI 1995, MF [=Malaisefalle], leg. S. Ungricht. 
COMMENTs: With its two (pairs of) scutellar setae this species is unique within Chamaepsila. For this reason Frey (1925) proposed the genus Tetrapsila for it with the remark that this genus may be only a subgenus of Chamaepsila. The two genera were indeed synonymized later (Shatalkin, 1986; Iwasa, 1998).

Chamaepsila pallida (Fallén, 1820)

Figs 2-3, P5-P6

Material Switzerland: 1 ơ, 1 q, BE, 650-950 m, Mt. Raimeux, Corcelles, 2 VI 2003, leg. B. Merz. $-1 \%$, BE, Burgdorf, leg. Meyer-Dür (small specimen). $-2 q$, GR, 1530-1540 m, Valbella, Casoja, 14-15 VII 1998, leg. B. Merz. - 10 , GR, 1530 m, Valbella, Casoja, 19 VII 1997, leg. B. Merz. - 1 q , GR, 1430 m, Zernez, Gondas, 6 VIII 1996, leg. B. Merz \& G. Bächli. -3 , , VS, 1400 m, Visperterminen, 14 VII 1995, leg. B. Merz.

Diagnosis: Ch. pallida is morphologically similar with Ch. luteola (Collin, 1944). They have both a yellow body. The latter differs from Ch. pallida by other proportions of its eye, the brownish dorsal border of the postpedicel (uniformly yellow in Ch. pallida), the brownish yellow setae on head and thorax (yellow in Ch. pallida) and the structure of the male terminalia (Wang, 1988). Two other species, Ch. nigrosetosa Frey, 1925, and Ch. unilineata (Zetterstedt, 1847), were often synonymized with $C h$. pallida. According to our studies we treat them here as good species. They may be separated from each other with the key provided at the end of this chapter.

COMmENTS: K. Holston from the NRS kindly made available photos of the entire type series of Scatophaga pallida Fallén (figs P5-P6). It contains one male, six females, and one specimen without abdomen. The male (fig. P5) and one female (fig. P6) carry an identification label in Fallén's handwriting. The male is labelled "S. pallida" (underlined), $\delta$ (written on the second line). The type locality is according to the original description "Esperöd" in Southern Sweden (Fallén, 1820). The specimen without abdomen belongs to another species, probably Chamaepsila rufa (Meigen, 1826), with its black setae on head and thorax. The abdomen is darkened in two females, and one of them has also the tip of the palpus darkened. They correspond probably to the description of Var. $\beta$ of Fallén. The male and the other four females are yellow including the palpus and are considered here as syntypes of Ch. pallida Fallén s. str. A short description of the male syntype (fig. P5) based partly on the study of the photos is provided here.

\section{DESCRIPTION MALE}

Head: Mostly yellow, but ocellar triangle blackish. Antenna entirely yellow, postpedicel about 1.6 times as long as wide at base. Arista yellowish, short setulose. Gena about 1.2 times less high than eye. Palpus yellow. Chaetotaxy (all setae light yellowish): 3 vertical setae; 1 stout postocellar seta; 2 fronto-orbital setae.

Thorax: Yellow including subscutellum. Chaetotaxy (all setae light yellowish): 1 notopleural seta; 2 dorsocentral setae posterior of suture; 1 (pair of) apical scutellar seta.

Legs: Yellow.

Wing: Hyaline with yellowish veins. Section of M1+2 between R-M and DM$\mathrm{Cu}$ about 2.9 times as long as previous section (between $\mathrm{BM}-\mathrm{Cu}$ and $\mathrm{R}-\mathrm{M}$ ) and slightly longer than last section (between DM-Cu and wing margin). Haltere yellowish white.

Abdomen: Entirely yellow. Genitalia (figs 2-3) with a wide aedeagus; paramere without a distinct, large tooth. 


\section{Chamaepsila pectoralis (Meigen, 1826)}

Material Switzerland: 1 , GR, 980 m, Andeer-Clugin, 17 VI 1994, leg. B. Merz. 1 \&, GR, 1490 m, Valbella-Casoja, 26 VII 1999, ZF, leg. B. Merz. - 1 oे, SG, 610 m, Wattwil, 11 VII 1997, leg. B. Merz. - 1 q , ZH, 400 m, Embrach-Haumüli, 4 VI 1998, leg. C. Wolf.

COMmENTs: The specimen from Valbella was collected in a tent-trap.

Chamaepsila persimilis (Wakerley, 1959)

Figs 4-5

Material Switzerland: 10 , GE, Corsier-Port, vitre véranda, 3-15 VIII 2003, leg. C. Besuchet. - 10े, 1 \% , GE, 420 m, Dardagny/Roulave, 30 VI 2001, leg. B. Merz. - 1 ô, GE, 360 m, Dardagny, Le Moulin, 30 VI 2001, leg. B. Merz. - 1 \&, GE, 350 m, Cartigny, Moulin de Vert, 5 VI 2006, leg. B. Merz. - 1 ô, GE, 360 m, Dardagny, Le Moulin, 8 VII 2002, leg. B. Merz. - 1 \% , GR, 980 m, Andeer (Hinterrhein), 29 VIII 2006, leg. B. Merz. - 5q, GR, 350 m, Grono (Dorf), 31 VIII 2006, leg. B. Merz. - 2 , GR, 330 m, Grono (Moesa), 31 VIII 2006, leg. B. Merz. - 1 , SG, $610 \mathrm{~m}$, Wattwil, 11 VII 1997, leg. B. Merz. - 2o, 1 , , VS, 460-750 m, Branson/Follatères, 9 VI 2004, leg. B. Merz \& J.-P. Haenni. - 1 q , VS, 1550 m, Visperterminen, ob Dorf, 27 VIII 2001, leg. B. Merz \& B. Landry. - 20 , VS, 920 m, Leuk-Brentjong, 15 V 2000, leg. B. Merz. - 1ઠิ, 2 \%, VS, 745 m, Visp, Hohbrunne, 3 VI 2003, leg. B. Merz. - 1 ๙ , ZH, 530 m, Zürich-Hönggerberg, 16 VI 1998, leg. B. Merz.

COMmEnTs: The aedeagus of this species is unique. According to the available illustrations (Wakerley, 1959; Lyneborg. 1964; van der Goot \& van Veen, 1996) and our observations (figs 4-5) it has a deep incision at its base which may be interpreted as a desclerotized area. In contrast, the lateral basal protuberances are strongly sclerotized. Moreover, the epandrium is unique by its extended and apically narrowed posteroventral margin (fig. 4).

\section{Chamaepsila quadrilineata (Strobl, 1898)}

Material Switzerland: 19 , VS, Jeitzinen, Ägerde, 3 VII 2001, leg. B. Merz. - $30 \hat{\text {, }}$ 2 q, VS, 1700-1900 m, Morgins, La Chaux-Culet, 21 VI 2003, leg. B. Merz. - $3 q$, VS, 2040 m, Morgins, Pointe de Bellevue, 21 VI 2003, leg. B. Merz.

\section{Chamaepsila rosae (Fabricius, 1794)}

Material Switzerland: $1 \sigma^{\star}$, GR, 1520 m, Lenzerheide-Sundroina, 12 VII 1999, leg. B. Merz. - 10 , GR, 1490 m, Valbella-Casoja, 24 VII 1999, leg. B. Merz. - 10 , VS, 700-770 m, Raron, Heidnischbiel, 26 V 1999, leg. B. Merz. - 10, VS, 1600-2200 m, Visperterminen, GiwGebidem, 4 VII 2003, leg. B. Merz.

COMMENTS: This is the noxious "carrot fly" whose larvae are tunneling roots of carrot, celery, parsnip, parsley and other umbelliferous plant species (Grichanov et al., 2005), It is widely distributed in the Palaearctic Region. In the Eastern Palaearctic Region it is recorded from China (Wang \& Yang, 1996), Mongolia (Soós, 1974), the Amur area (Shatalkin, 1986), and the Sakhalin and Kuril Islands. Surprisingly it has not yet been found in the Primorye Territory of Russia, maybe because this species is replaced there by the morphologically (and maybe biologically) similar species $C h$. sonora (Shatalkin, 1986) and Ch. iwasai (Shatalkin, 1996) which were found in a garden of a kitchen. Although Ch. rosae is known from Japan it is rare because another species, Synaphopsila nartshukae Shatalkin, 1986, is known to damage carrots (Iwasa et al., 1987; Narita et al., 2005). Later, the species was accidently introduced to North America where it is now a pest species (Hooper et al., 2002) and to New Zealand (Evenhuis, 1989). 
The name Musca rosae Fabricius, 1794, is a primary homonym of Musca rosae De Geer, 1776 (a junior synonym of the Syrphidae Musca pyrastri Linnaeus, 1758) (Thompson \& Pont, 1994) and the new name Chamaepsila hennigi Thompson \& Pont, 1994, was proposed for the carrot fly. Later, Chandler (1998b) requested the ICZN to preserve the name "rosae" for the carrot fly, and this proposition was accepted (ICZN, 1999).

The identity of the Swiss specimens was confirmed by dissection of the male terminalia and the comparison with illustrations published by Wakerley (1959), Lyneborg (1964) and Wang (1988).

Chamaepsila sardoa (Rondani, 1876) - new for Switzerland

Material Switzerland: 1 \% , TI, 205 m, Gordola, Verzascaufer, 15 V 2006, leg. B. Merz. - 10ิ , 1 우, TI, 205 m, Gordola, Verzascaufer, 1 IV 2007, leg. B. Merz.

Comments: This species is in most respects similar to Ch. buccata. It may be separated from the latter and from Ch. rozkosnyi, another morphologically similar species, by the characters mentioned under Ch. buccata. Ch. sardoa is a Mediterranean species which has been found from Spain to Israel. The present finding in Southern Switzerland represents the northernmost record of this species. Outside the Western Palaearctic Region it was recorded from desert zones in Middle Asia and from Mongolia (Soós, 1974). The record from Myanmar by Frey (1955) is based on a misidentification. He compared his female from Mt. Kambaiti with a female from Morocco which he thought was Ch. sardoa. A careful study of both specimens revealed that they belong to two different species. The female from Morocco was later described as Psila atlasica Shatalkin, 2000, and the female from Myanmar as Psila freyi Shatalkin, 2000.

Chamaepsila unilineata (Zetterstedt, 1847) stat. rev. - new for Switzerland Figs 6-7 Material SWITZERLAND:

A) Typical sPeCimens: 10 , GR, 1000-1150 m, Brienz-Surava, 25 VII 1999, leg. B. Merz. - 1 ㅇ, GR, 1550 m, Lenzerheide/Sundroina, 20 VII 1997, leg. B. Merz. -60 , 3 \% , GR, 1520 m, Lenzerheide/Sundroina, 10 VII 1998, leg. B. Merz. - 60ิ, 2q, GR, 1490 m, Lenzerheide/See, 11 VII 1998, leg. B. Merz. - 1 \% , GR, 1500 m, Valbella, Casoja, 21 VII 1997, leg. B. Merz. - 1 ㅇ, GR, 1530 m, Valbella, Casoja, 14 VII 1998, leg. B. Merz. -20 , 3 \% , GR, 1490 m, Valbella, Casoja, 24 VII 1999, leg. B. Merz. - 4 q, TI, 1097 m, Mte. S. Giorgio, top, 18 V 2006, leg. B. Merz. - 60 , 3 ㅇ, VS, $1550 \mathrm{~m}$, Jeitzinen, 26 VI 1999, leg. B. Merz \& M.

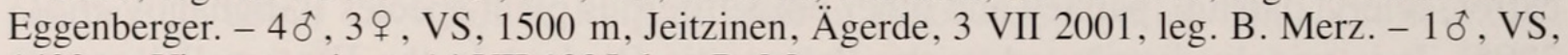
$1400 \mathrm{~m}$, Visperterminen, 14 VII 1995, leg. B. Merz.

B) LONGITUDINAL STRIPES ON MESONOTUM BADLY EXPRESSED OR ABSENT: 1 औ , GR, $980 \mathrm{~m}$, Andeer, Clugin, 17 VI 1994, B. Merz. - 2 9, GR, 1550 m, 3 km N Lenz, 11 VII 1996, leg. B. Merz. - 20 , 2 \% , GR, 1520 m, Lenzerheide/Sundroina, 10 VII 1998, leg. B. Merz. - 1 \%, GR, $1600 \mathrm{~m}$, Lenzerheide/Sundroina, 16 VII 2000, leg. B. Merz. - 50, 1\%, GR, $1490 \mathrm{~m}$, Lenzerheide/See, 11 VII 1998, leg. B. Merz. - 10 , GR, 1500 m, Valbella, Casoja, 19 VII 1997, leg. B. Merz. - 3o , 2 ㅇ, GR, 1490 m, Valbella, Casoja, 24 VII 1999, leg. B. Merz. - 2 ô, 1 의, GR, 1000-1150 m, Brienz-Surava, 25 VII 1999, leg. B. Merz. - 20 , TI, 1097 m, Mte. S. Giorgio, top, 18 V 2006, B. Merz. - 1 , ZH, 350 m, Flaach, Thurauen, 6 VI 1993, leg. B. Merz.

C) Katepisternum BRownISH: 1 \% , GR, 1520 m, Lenzerheide/Sundroina, 10 VII 1998, leg. B. Merz. - 10 , GR, 1490 m, Valbella, Casoja, 24 VII 1999, leg. B. Merz. - $50^{\dagger}, 4$, , VS, $1550 \mathrm{~m}$, Jeitzinen, 26 VI 1999, leg. B. Merz \& M. Eggenberger. - 26, 1 \%, VS, 1500 m, Jeitzinen, Ägerde, 3 VII 2001, leg. B. Merz. 
Comments: So far, this species has usually been synonymized with Chamaepsila pallida (Fallén). It was argued that the presence of three dark longitudinal stripes on the yellow mesonotum and the dark subscutellum fall within the colour variation of Ch. pallida (Hennig, 1941; Soós, 1984, 1985). However, a careful study including the structure of the male terminalia has shown that two species are involved. They differ in the colour of the subscutellum which is yellow in Ch. pallida but has a brown median stripe in Ch. unilineata A brief diagnosis of Ch. unilineata is provided here.

\section{DESCRIPTION MALE}

Head: Antenna with postpedicel yellow, rarely with a narrow or wide brownish dorsal margin. Arista rather long setulose (as in Hennig, 1941, fig. 19, right illustration); Palpus yellow.

Thorax: Mesonotum yellow, with a medial and a pair of lateral brown to black, narrow to wide stripes which may be conspicuous or more or less reduced or even almost absent. Subscutellum at least medially brown to black. Katepisternum yellow or with brown spot of various size.

Male terminalia: Aedeagus rather narrow, triangular. Paramere with four large teeth (figs 6-7).

\section{Chamaepsila villosula (Meigen, 1826)}

Material Switzerland: 40ิ, GR, 2100 m, Ftan/Clünas, 5 VIII 1996, leg. B. Merz \& G. Bächli. - 1 ઈे, VS, 1500 m, Jeitzinen, Ägerde, 3 VII 2001, leg. B. Merz.

COMmENTs: This species is easy to identify because of its colouration, chaetotaxy and the male terminalia with the large epandrium. It is rarely collected and its distribution is therefore little known. Pape (2007) recorded it from Belgium, Germany, Czech and Slovak Republics, Hungary, and Switzerland. Recently, it was found in Italy (Verona province, Chiesa S. Michele, 26 VI 2001, leg. B. Merz \& F. Mason, MHNG) and in France (Hautes-Alpes, Montgenèvre, 1800 m, VII, leg. M. Barták, ZMUM).

\section{TAXONOMIC REMARKS CONCERNING THE CHAMAEPSILA PALLIDA GROUP}

Frey (1925) attempted to classify the species of Chamaepsila into more or less homogenous, "natural" groups based on their chaetotaxy. His "Gruppe 3", here called Chamaepsila pallida group, is characterized by the presence of 3 vertical setae, 2 dorsocentral setae posterior the suture and 1 well-developed postocellar seta. Body colour varies from almost entirely black (Ch. rosae subgroup, including $C h$. confusa, Ch. humeralis, Ch. nigricornis, Ch. persimilis, Ch. rosae) to partly yellow and partly black (Ch. pectoralis subgroup with $C h$. pectoralis and Ch. strigata) to almost entirely yellow (Ch. pallida subgroup). The latter subgroup is taxonomically the most difficult one. The following seven species which are recognized here as valid are assigned to this subgroup: Ch. andreji (Shatalkin, 1996), Ch. luteola (Collin, 1944), Ch. nigro setosa Frey, 1925, Ch. ozerovi (Shatalkin, 1993), Ch. pallida (Fallén, 1820), Ch. triorbiseta Papp, 2003, and Ch. unilineata (Zetterstedt, 1847). Two of these species, Ch. nigrosetosa and $\mathrm{Ch}$. unilineata, are subject to various interpretations by different students of the family and their status is revised here based on the study of additional specimens. 
Chamaepsila nigrosetosa was described from one female from Finland. Hennig (1941) considered it as a colour morph of Ch. pallida, and Soós (1984) followed this interpretation. However, it differs from the latter clearly in several external characters and this may be the reason why it was recognized as a good species in the recent checklist of Diptera of Czech and Slovak Republics (Barták \& Carles-Tolrá, 2006) and in the Fauna Europaea database (Pape, 2007).

The status of Ch. unilineata was often questioned in the past, and it was usually treated as a colour form of Ch. pallida (see above, under this species). Zetterstedt (1847) provided a rather good description which allows to differentiate it from the other species of Chamaepsila known at that time, especially from Ch. pallida. Unfortunately, Wang (1988) in her revision of the West Palaearctic Chamaepsila, dissected only one male of the "typical" Ch. pallida, but none of the form with black stripes ("Ch. unilineata") and she treated Ch. unilineata as a variety of Ch. pallida in the key. On the other hand, Barták \& Carles-Tolrá (2006) and Pape (2007) considered both species as valid. It should be mentioned here that Séguy (1934) distinguished the two species in his key, one as Ch. pallida, the other as Ch. debilis (Egger, 1862). From his descriptions it is evident that his "Ch. debilis" corresponds with the original description of Ch. unilineata. He thought to follow basically the interpretation of Schiner (1863) who included the two species (pallida and debilis) in his key of Austrian Diptera. However, the description of "Psila debilis" sensu Schiner corresponds better with the current interpretation of Ch. nigrosetosa than of Ch. unilineata (which was diagnosed by Schiner in a footnote). The problems concerning the status of Ch. unilineata may be explained by the high variability of its external characters, in particular the development of the longitudinal, black, narrow stripes on the mesonotum which may be conspicuous, faint or absent (see "Material" above under Ch. unilineata). However, based on a careful study of numerous specimens it is concluded here that both species are valid and may be separated based on a combination of external and genitalian characters. In order to facilitate identification, an updated key for species of the Ch. pallida group is provided here.

\section{A SHORT KEY TO SPECIES OF THE EUROPEAN SPECIES OF THE CHMAE - PSILA PALLIDA GROUP}

This key is based basically on external characters. Illustrations of the male terminalia may be found in Shatalkin (1986) and Wang (1988) for most species described until then and in the original descriptions for the species described since then. The species marked with an asterisk (*) were studied by us. The other species were included in the key based on their original descriptions.

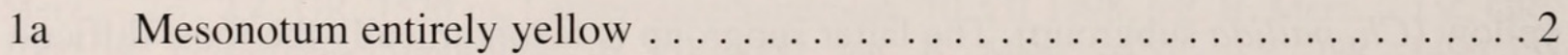

1b Mesonotum yellow with black stripes or entirely black $\ldots \ldots \ldots \ldots \ldots$

2a Subscutellum yellow. Arista short setulose, rays shorter than basal

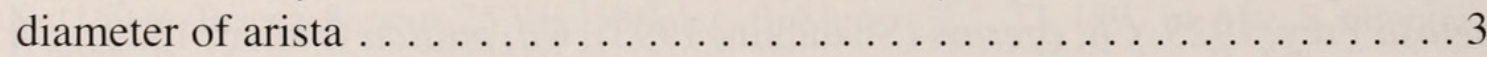

2b Subscutellum brown or black at least medially. Arista long setulose, rays longer than basal diameter of arista (see Hennig 1941, fig. 19, right illustration) ........... Chamaepsila unilineata (Zetterstedt, 1847) partim* (=Ch. pallida auct. nec. Fallén) 
$10 \mathrm{~b}$

11a

$11 b$

Abdominal tergites black, Palpus apically black .............. 4

Abdominal tergites yellow. Palpus yellow, or narrowly brownish apically . . 6 3 fronto-orbital setae present. Frons yellow, with a transverse black stripe dorsally the lunule. Body length: $3.45 \mathrm{~mm}$. - Hungary .

Chamaepsila triorbiseta Papp, 2003

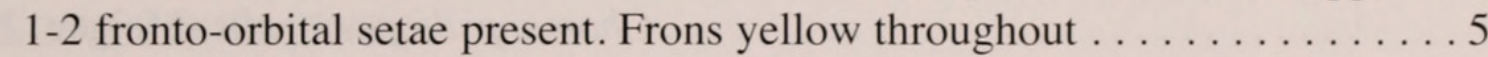
Postpedicel black. Setae on head and thorax ranging from yellow (specimens from the Caucasus) to dark brown (specimens from Northern Italy). Body length: $3.3 \mathrm{~mm}$. - Russia (Caucasus), Italy

Chamaepsila andreji (Shatalkin, 1996)*

Postpedicel mainly yellow, with a darkened dorsal margin. Setae on head and thorax black. Body length: $4.5 \mathrm{~mm}$. - Finland, Czech and Slovak Republics, Russia (Moscow area) ..... Chamaepsila nigrosetosa Frey, 1925* Postpedicel yellow. Setae on head and thorax light yellow. Body length: 4.0-5.0 mm. - Europe, Mongolia (?) ... . Chamaepsila pallida (Fallén, 1820)* Postpedicel mainly yellow, with a darkened dorsal margin. Palpus often narrowly brownish apically. Setae on head and thorax brownish yellow. Body length: $4.0 \mathrm{~mm}$. - Great Britain, Denmark, Czech and Slovak Republics, Russia (Moscow area) ....... Chamaepsila luteola (Collin, 1944)* a Mesonotum yellow, with 3 longitudinal stripes. Pleuron yellow. Postpedicel mainly yellow, sometimes with a darkened dorsal margin. Arista long setulose, rays longer than basal diameter of arista (see Hennig 1941, fig. 19, right illustration). Male: Aedeagus narrow and paramere with four large teeth (figs 6-7). Body length: 4.0-5.0 mm Europe ............ Chamaepsila unilineata (Zetterstedt, 1847) partim* Mesonotum entirely black. Other characters variable ............ 8 Pleuron black, or black with a yellowish spot dorsally the anterior

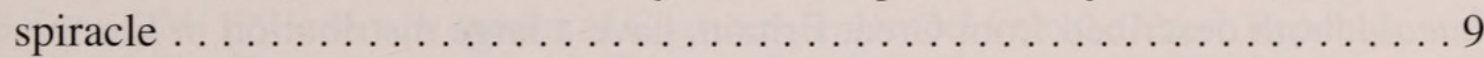

Pleuron partly or entirely yellow, at least postpronotal lobe yellow...... 12 Pleuron with a yellowish spot dorsally the anterior spiracle. Praelabrum

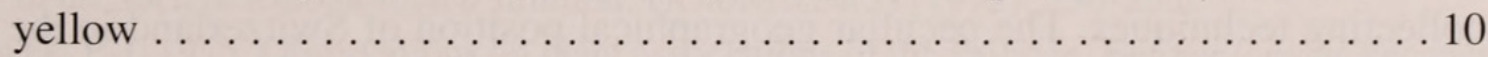

Pleuron entirely black. Praelabrum black ... . . . . . . . . . . . 11

Palpus yellow, rarely brownish infuscated. Postpedicel black but yellow ventrally at base. Male: terminalia as in figs 4-5. Body length: 3.5$3.8 \mathrm{~mm}$. - Europe ........... Chamaepsila persimilis (Wakerley, 1959)* Palpus black in apical half. Postpedicel entirely black. Male: terminalia as in fig. 1. Body length: 3.7-4.2 mm. - France, Switzerland . .

\section{Chamaepsila confusa sp. n.*}

Postpedicel black, but with a small yellow spot dorsally at base around and/or basally the insertion of the arista. Body length: 3.2-3.8 mm. Holarctic species . . . . . . . . . Chamaepsila rosae (Fabricius, 1794)* Postpedicel entirely black. Body length: 3.4-4.2 mm. - Palaearctic, Oriental (Myanmar), Afrotropical (Kenya?) Regions . . . 
12a Pleuron black, but postpronotal lobe (always) and sometimes also anepimeron yellow. Body length: 2.8-3.7 mm. - Europe . . . . . . . . . Chamaepsila humeralis (Zetterstedt, 1847)*

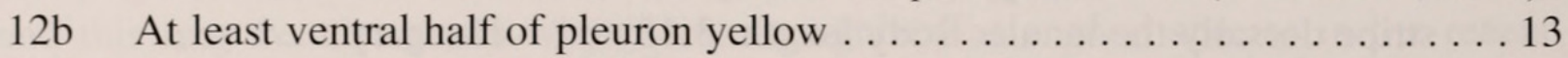

13a Pleuron entirely yellow. Body length: 2.7-3.2 mm. - Europe . . . . . . . .

.Chamaepsila pectoralis (Meigen, 1826)*

13b Pleuron bicoloured, dorsal half black, ventral half yellow. Body length:

3.0 mm. - Montenegro . . . . . . . . . Chamaepsila strigata (Collin, 1959)

\section{CONCLUSIONS}

The present paper summarizes the present knowledge of the family Psilidae for Switzerland and discusses some taxonomical problems related to the European fauna. Up to 1998 reliable data for 6 species only were published from Switzerland (Ringdahl, 1957). They were all discovered after 1990 again. Whereas 32 species have been recorded from Switzerland in the checklist and its first supplement (Merz, 1998; Merz et al., 2002), another 4 species are added here including two species new to science. Currently, 36 species are known with certitude from this country. Based on the checklists of other Central European countries (Germany, the Netherlands, Czech and Slovak Republics, Hungary) and our knowledge of the general distribution of the species it may be expected that another 6 species at least may be found with more extensive field work focused on this family. They are often either rare in collections, they have been overlooked due to their similarity with common species, or they were misidentified by non-expert entomologists. This list of expected species comprises Chamaepsila andreji (Shatalkin, 1996), Ch. clunalis (Collin, 1944), Ch. luteola (Collin, 1944), Ch. rozkosnyi Carles-Tolrá, 1993, Ch. rufa (Meigen, 1826), and Ch triorbiseta Papp, 2003. For instance, Ch. andreji and Ch. rozkosnyi were recently discovered in Northern Italy less than $50 \mathrm{~km}$ from the Swiss border, Ch. clunalis and Ch. luteola, both described from Great Britain, have a large distribution in Europe, as it is the case for Ch. rufa. On the other hand, Ch. triorbiseta was described few years ago from a single female only. It seems to be a rare species and may require special collecting techniques. The peculiar geographical position of Switzerland in the center of Europe with influences from various climatic areas allowed the occurrence of a diverse fauna with elements from different parts of Europe. The following three major elements constitute the Psilidae fauna of Switzerland. The largest number is represented by species which have a large distribution in Europe or even the entire Palaearctic Region (for instance, Chamaepsila nigricornis, Ch. rosae, Psila fimetaria). The second element comprise boreal and subarctic species of higher altitudes (generally the Alps) in Switzerland, like the two species of Psilosoma, Chamaepsila atra, or Ch. morio. Finally, Chamaepsila sardoa is recorded here for the first time from Southern Switzerland which represents the northernmost record of this Mediterranean element.

A new insight into some difficult species groups of Chamaepsila is presented here. In particular, the status of $C h$. unilineata is revised based on numerous specimens from Switzerland. They allow to conclude that it is a good species clearly different from $C h$. pallida with which it was usually synonymized. An updated key should permit to identify this and the other species of the Ch. pallida group with more confi- 
dence. However, additional work is needed in order to understand fully the taxonomy of the difficult genus Chamaepsila. In particular, the study of some types should allow to fix the status of some of the enigmatic species which are known from few specimens or the type series only.

\section{ACKNOWLEDGEMENTS}

We wish to thank the following colleagues for much helpful advise and assistance during the preparation of this study (in alphabetical order): Dr. M. Barták (Czech University of Agriculture, Prague, Czech Republic), Dr. A. Freidberg (Tel-Aviv University, Tel-Aviv, Israel), Dr. Kevin Holston (Swedish Museum of Natural History, Stockholm, Sweden), Dr. Vladislav Martinek $\dagger$, Dr. A. L. Ozerov (Zoological Museum, Moscow State University, Russia) and Dr. Laszlo Papp (Hungarian Natural History Museum, Budapest, Hungary). The second author is indebted to many colleagues for their company during the numerous field trips and for the specimens they put at our disposal (see under "Material " for their names). For technical help we express our best thanks to Florence Marteau, Corinne Reuteler, and Philippe Wagneur (MHNG).

\section{REFERENCES}

Barták, M. \& Carles-Tolrá, M. 2006. Psilidae Loew, 1861. In: Jedlicka, L., Stloukalová, V. \& Kudela, M. (eds). Checklist of Diptera of the Czech Republic and Slovakia. Bratislava, Comenius University. Accessible at: http://zoology.fns.uniba.sk/diptera (accessed 2 May 2010).

Buck, M. \& Marshall, S. A. 2006a. The identity of Pseudopsila, description of new subgenus of Psila, and redefinition of Psila sensu lato (Diptera: Psilidae). European Journal of Entomology 103: 183-192.

Buck, M. \& Marshall, S. A. 2006b. Revision of New World Loxocera (Diptera: Psilidae), with phylogenetic redefinition of Holarctic subgenera and species groups. European Journal of Entomology 103: 193-219.

CArles-Tolrá, M. 1993a. A new species of Chamaepsila Hendel from the Czech Republic, with a key to the bicolor-group species (Diptera: Psilidae). Graellsia 49: 91-95.

Carles-Tolrá, M. 1993b. Two new species of Psilidae and Tethinidae from Spain. Bollettino della Società Entomologica Italiana, Genova 124(3) (1992): 250-253.

ChAndler, P. J. 1975. Observations on plant associations of the Psilidae. Entomological Records and Journal of Variation 87: 13-17.

Chandler, P. J. 1998a. Psilidae (pp. 118-119). In: Chandler, P. J. (ed.). Checklists of Insects of the British Isles (New Series). Part 1: Diptera. Handbooks for the Identification of British Insects 12: 1-234.

Chandler, P. 1998b. Case 3068. Musca rosae Fabricius, 1794 (currently Psila or Chamaepsila rosae (Insecta, Diptera): proposed conservation of the specific name. Bulletin of Zoo logical Nomenclature 55(2): 96-98.

Collin, J. E. 1944. The British Species of Psilidae (Diptera). Entomologist's Monthly Magazine 80: $214-224$.

De MeiJere, J. C. H. 1940. Über die Larven der in Orchideen minierenden Dipteren. Tijdschrift voor Entomologie 83: 122-127.

De Meijere, J. C. H. 1941. Pupariën van Loxocera in stengels van Juncus. Entomologische Berichten Amsterdam 10: 286-287.

Dengler, K. 1997. Zur Lebensweise von Chyliza leptogaster Panzer und Ch. nova Collin (Psilidae, Diptera) und ihre Bedeutung als Urheber von Bastnekrosen an Laubbäumen. Studia Dipterologica 4(1): 143-164. 
Evenhuis, N. L. 1989. 59. Family Psilidae (p. 473). In: Evenhuis, N. L. (ed.). Catalog of the Diptera of the Australasian and Oceanian Regions. Bishop Museum Press, Honolulu \& E. J. Brill, Leiden, 1155 pp.

Fallén, C. F. 1820. Opomyzides Sveciae. Lundae, 12 pp.

FERRAR, P. 1987. A Guide to the Breeding Habits and Immature Stages of Diptera Cyclorrhapha. Entomonograph 8(1): 1-478.

Freidberg, A. \& Shatalkin, A. I. 2009 (2008). The Psilidae (Diptera) of Israel, with emphasis on the Chamaepsila hebraica group. Israel Journal of Entomology 38 (2008): 35-60.

FREY, R. 1925. Zur Systematik der paläarktischen Psiliden (Dipt.). Notulae entomologicae 5: 47-50.

Frey, R. 1955. Studien über ostasiatische Dipteren V. Psilidae, Megamerinidae. Notulae entomologicae 35: 122-137.

Greve, L. \& Midtgaard, F. 1989. The genus Chyliza (Dipt., Psilidae) in Norway. Fauna Norvegica (Serie B) 36: 139-140.

Greve, L. \& Skartveit, J. 2000. The genus Loxocera (Diptera, Psilidae) in Norway. Norwegian Journal of Entomology 48: 329-334.

Grichanov, I. Y., Ovsyannikova, E. I., Saulich, M. I. \& Shatalkin, A. I. 2005. Area and zone of harmfulness of Chamaepsila rosae (Fabr.) (Diptera, Psilidae). Vestnik zashchity rastenii (Plant Protection News) (Saint-Petersburg-Pushkin) 1: 73-75 (in Russian).

Hendel, F. 1917. Beiträge zur Kenntnis der acalyptraten Musciden. Deutsche entomologische Zeitschrift 1917: 33-47.

Hendel, F. 1934. Schwedisch-chinesische wissenschaftliche Expedition nach den nordwestlichen Provinzen Chinas. 13. Diptera. 5. Muscaria holometopa. Arkiv för zoologi B $25 \mathrm{~A}(21)$ (1933): 1-18.

Hennig, W. 1941. 41. Psilidae. In: Lindner, E. (ed.). Die Fliegen der Palaearktischen Region. Volume 5, Lieferung 140. Schweizerbart'sche Verlagsbuchhandlung, Stuttgart, 38 pp.

HoOper, L. R. E., DiXON, P. L. \& LARSON, D. J. 2002. Distribution and seasonal activity of adult carrot rust flies (Diptera: Psilidae). The Canadian Entomologist 134(5): 703-706.

ICZN (INTERnational COMmission OF Zoological Nomenclature). 1999. Opinion 1938. Musca rosae Fabricius, 1794 (currently Psila or Chamaepsila rosae; Insecta, Diptera): specific name conserved. Bulletin of Zoological Nomenclature 56(3): 216-217.

IwASA, M. 1998. 3. 11. Family Psilidae (pp. 177-183). In: PAPP, L. \& DARvas, B. (eds). Contri butions to a Manual of Palaearctic Diptera. Volume 3. Science Herald, Budapest, $880 \mathrm{pp}$.

Iwasa, M., HanAda, T. \& KaJINO, Y. 1987. A new psilid species from Japan injurious to the root of carrot (Diptera: Psilidae). Applied entomology and zoology 22(3): 310-315.

Johnson, C. W. 1920. A revision of the species of the genus Loxocera, with a description of a new allied genus and a new species. Psyche 27: 15-19.

LyneborG, L. 1964. Danske acalyptrate fluer. 2. Psilidae, Platystomidae og Otitidae (Diptera). Entomologiske Meddelelser 32: 367-388.

LyNeBORG, L. 1987. On the life history of Chyliza annulipes Macquart, 1835 (Diptera: Psilidae). Entomologiske Meddelelser 55: 27-29.

McAlpine, D. K. 1997. Gobryidae, a new family of Acalyptrate flies (Diptera: Diopsoidea), and a discussion of relationships of the Diopsoid families. Records of the Australian Museum 49: $167-194$.

Melander, A. L. 1920. Synopsis of the dipterous family Psilidae. Psyche 27: 91-101.

Merz, B. 1998. 58. Psilidae (pp. 238-239). In: Merz, B., BÄchli, G., Haenni, J.-P. \& Gonseth, Y. (eds). Diptera - Checklist. Fauna Helvetica 1: 1-369.

Merz, B. \& HaenNI, J.-P. 2000. 1.1. Morphology and terminology of adult Diptera (other than terminalia) (pp. 21-51). In: PAPP, L. \& DARvas, B. (eds). Contribution to a Manual of Palaearctic Diptera. Volume 1. Science Herald, Budapest, 978 pp.

Merz, B., BÄChli, G. \& HaEnNI, J.-P. 2002. Erster Nachtrag zur Checkliste der Diptera der Schweiz. Mitteilungen der Entomologischen Gesellschaft Basel 51(3/4) (2001):110-140.

Merz, B., BÄChl, G. \& HaEnNI, J.-P. 2007. Zweiter Nachtrag zur Checkliste der Diptera der Schweiz. Mitteilungen der Entomologischen Gesellschaft Basel 56(4) (2006): 135-165. 
Narita, O., Oikawa, K., Satoh, M. \& Fujimura, T. 2005. Occurrence of Psila (Synaphopsila) nartshukae (Diptera: Psilidae) injurious to roots of carrot in Aomori Prefecture. Annual Report of the Society of Plant Protection of North Japan 56: 134-136.

PAPE, T. 2007. Fauna Europaea: Psilidae. In: PAPE, T. (ed.). Fauna Europaea: Diptera, Brachycera. Version 1.3. http://www.faunaeur.org (accessed 8 May 2010).

Petit, J. 1982. Chronique de la Montagne Saint-Pierre IX. Un orchidophile peu ordinaire: Chyliza vittata Meigen (Diptères, Psilidés). Revue verviétoise d'histoire naturelle 39: 61-64.

RINGDAHL, O. 1957. Fliegenfunde aus den Alpen. Entomologisk Tidskrift 78: 115-138.

Schacht, W. 1996. Zweiflügler aus Bayern X (Diptera: Pseudopomyzidae, Micropezidae, Tanypezidae, Megamerinidae, Psilidae). Entomofauna 17(14): 264-268.

Schiner, J. R. 1863. XXI. Fam. Muscidae. XVII. Abtheilung. Psilinae (pp. 196-207). In: Die Fliegen (Diptera). Fauna Austriaca. Volume 2. Wien, XXXII \& 658 pp.

SÉGUY, E. 1934. Diptères (Brachycères) (Muscidae Acalypterae et Scatophagidae). Faune de France 28: IV \& 832 pp.

SÉGuY, E. 1936. Voyage de MM. L. Chopard et A. Méquignon aux Açores (août-septembre 1930). X. Diptères. Annales de la Société entomologique de France 105: 11-26.

Shatalkin, A. I. 1983. New species of flies of the family Psilidae (Diptera) from the Far East. Entomologicheskoe obozrenie 62: 360-366 (in Russian).

Shatalkin, A. I. 1986. Review of the eastpalaearctic flies of Psila Mg. (Diptera, Psilidae), with the key of the Palaearctic species. Trudy Zoologicheskogo Instituta AN SSSR, Leningrad 146: 23-43 (in Russian).

Shatalkin, A. I. 1989. Notes on the Palaearctic Psilidae (Diptera). Archives of the Zoological Museum of the Moscow State University 27: 88-113 (in Russian).

Shatalkin, A. I. 1998. Asian species of Loxocera Meigen (Diptera: Psilidae). Russian Entomo logical Journal 6(3-4) (1997): 87-97.

ShatAlKIn, A. I. 2001. Afrotropical Psilidae (Diptera). 1. Genera Belobackenbardia gen. n. and Psila Meigen, 1803. Russian Entomological Journal 10(4): 417-424.

Shatalkin, A. I. 2008. East Palaearctic and Oriental flies of the genus Psila Meigen (Psilidae). Archives of the Zoological Museum of the Moscow State University 49: 48-69 (in Russian).

Shtakel'Berg, A. A. 1989. 57. Family Psilidae (pp. 184-191). In: Bei-BienKo, G. YA. (ed.). Diptera and Siphonaptera. Keys to Insects of the European Part of the USSR. Volume V. Part 2, XXII \& 1505 pp.

Soós, Á. 1974. Taxonomische und faunistische Untersuchungen über die Psiliden (Diptera) aus der Mongolei. Annales Historico-Naturales Musei Nationalis Hungarici 66: 241-250.

Soós, Á. 1982. Untersuchungen des Typenmaterials der Rondani'schen Sammlung. 1. Psilidae (Diptera). Folia Entomologica Hungarica 43(1): 155-158.

Soós, Á. 1984. Family Psilidae (pp. 28-35). In: Soós, Á. \& PAPP, L. (eds). MicropezidaeAgromyzidae. Catalogue of Palaearctic Diptera. Volume 9. Akadémiai Kiadó, Budapest, $460 \mathrm{pp}$.

Soós, Á. 1985. Untersuchungen einiger Psilide-Typen aus der Zetterstedt'schen Sammlung nebst Beschreibung einer neuen Art (Diptera: Psilidae). Acta Zoologica Hungarica 31: 235-244.

Steyskal, G. C. 1987. 60. Psilidae (pp. 781-784). In: McAlpine, J. F., Peterson, B. V., Shewell, G. E., Teskey, H. J., Vockeroth, J. R. \& Wood, D. M. (eds). Manual of Nearctic Diptera. Volume 2. Research Branch, Agriculture Canada, Monograph 28: 675-1332.

Thompson, F. C. \& Pont, A. C. 1994. Systematic database of Musca names (Diptera). Theses Zoologicae 20: 1-219.

VAN DeR Goot, V. S. \& van Veen, M. P. 1996. De Spillebeenvliegen, Wortelvliegen en Wolzwevers van Noordwest-Europa. Jeudbondsuitgeverij, Utrecht, 57 pp. 
VERnON, J. D. R. 1962. Observation on the biology and control of the Chrysanthemum stool miner. Plant Pathology 11(1): 38-40.

Wakerley, S. B. 1959. A new species of Psila Meigen (Diptera: Psilidae) from Northern England. Proceedings of the Royal entomological Society of London (B) 28(7-8): 107-108.

WANG, X. 1988. Bestimmungstabellen der westpaläarktischen Chamaepsila-Arten (Diptera: Psilidae). Stuttgarter Beiträge zur Naturkunde, Serie A 417: 1-13.

Wang, X. \& Yang, C. 1996. Psilidae (pp. 424-456). In: Xue, W. \& СhaO, Ch. (eds). Flies of China. Volume 1. Liaoning Science and Technology Press, Shenyang: 1-1365.

YANG, C. \& WANG, X. 1988. A new species of Chyliza (Psilidae: Diptera) from China, injuring bamboo roots. Forest Research 1: 275-277.

Zetterstedt, J. W. 1860. Diptera scandinaviae disposita et descripta. Volume 14. Lundae, 6191-6609.

\section{APPENDIX}

A REVISED CHECKLIST OF THE PSILIDAE OF SWITZERLAND

The following abbreviations are used behind the names: $\mathrm{N}=$ New record for Switzerland in the present paper; R1 = Merz (1998); R2 = Merz et al. (2002)

\section{Subfamily Chylizinae}

Chyliza Fallén, 1820

- annulipes Macquart, 1835 R1

- extenuata (Rossi, 1790) R1

- leptogaster (Panzer, 1798) R1

- nova Collin, $1944 \mathrm{R} 1$

- vittata Meigen, 1826 R1

SubFamily PsiLinaE

Tribe Loxocerini

Imantimyia Frey, 1925

- albiseta (Schrank, 1803) R1

- fulviventris (Meigen, 1826) R1

- nigrifrons (Macquart, 1835) R1

- sylvatica (Meigen, 1826) R1

\section{Loxocera Meigen, 1803}

subgenus Loxocera Meigen, 1803

- aristata (Panzer, 1801) R1

- maculata Rondani, 1876 R2

subgenus Platystyla Macquart, 1835

- hoffmannseggi Meigen, 1826 R1

Tribe Psilini

\section{Chamaepsila Hendel, 1917}

- atra (Meigen, 1826) R1

- bicolor (Meigen, 1826) R1

- buccata (Fallén, 1826) R1
- confusa Shatalkin \& Merz, sp. n. N

- humeralis (Zetterstedt, 1847) R1

- limbatella (Zetterstedt, 1847) R1

- morio (Zetterstedt, 1835) R1

- nigra (Fallén, 1820) R1

- nigricornis (Meigen, 1826) R1

- obscuritarsis (Loew, 1856) R1

- pallida (Fallén, 1820) R1

- pectoralis (Meigen, 1826) R1

- persimilis (Wakerley, 1959) R1

- quadrilineata (Strobl, 1898) R1

- rosae (Fabricius, 1794) R1

- sardoa (Rondani, 1876) N

- unilineata (Zetterstedt, 1847) N

- villosula (Meigen, 1826) R1

Psila Meigen, 1803

subgenus Oxypsila Frey, 1925

- abdominalis Schummel, 1844 R1

subgenus Psila Meigen, 1803

- fimetaria (Linnaeus, 1761) R1

- helvetica Shatalkin \& Merz, sp. n. N

- merdaria Collin, 1944 R1

Psilosoma Zetterstedt, 1860

- audouini (Zetterstedt, 1835) R1

- lefebvrei (Zetterstedt, 1835) R1 


\section{$2 \mathrm{BHL}$ Biodiversity Heritage Library}

Shatalkin, Anatole I and Merz, Bernhard. 2010. "The Psilidae (Diptera, Acalyptrata) of Switzerland, with description of two new species from Central Europe." Revue suisse de zoologie 117, 771-800.

https://doi.org/10.5962/bhl.part.117602.

View This Item Online: https://www.biodiversitylibrary.org/item/148553

DOI: https://doi.org/10.5962/bhl.part.117602

Permalink: https://www.biodiversitylibrary.org/partpdf/117602

\section{Holding Institution}

American Museum of Natural History Library

\section{Sponsored by}

BHL-SIL-FEDLINK

\section{Copyright \& Reuse}

Copyright Status: In copyright. Digitized with the permission of the rights holder.

Rights Holder: Muséum d'histoire naturelle - Ville de Genève

This document was created from content at the Biodiversity Heritage Library, the world's largest open access digital library for biodiversity literature and archives. Visit BHL at https://www.biodiversitylibrary.org. 